\title{
THE ROLE OF ISLAMIC ECONOMY IN REDUCTION OF SOCIAL INJUSTICE AND SUSTAINABLE DEVELOPMENT GOALS
}

\begin{abstract}
Today, the most severe problems faced by people are the income injustice and increase of poverty. During the rapid change process that began in the 1980 s, the problem of the income distribution was no longer perceived as a common economic problem, but as a political and social problem. Economic and social policies implemented since the 1950s have not been able to solve the problems and have made many problems more apparent. In short, in today's world, an unbalanced structure has emerged, where financial prosperity is increasing, and social welfare is gradually diminishing.

This study addresses three main problems (i) what the answers to a more livable life expectancy that will meet the needs of everyone and every sector based on the understanding that the Islamic economy has a future-oriented understanding, (ii) what are the strategies for eliminating injustices in income distribution in terms of Islamic economy are? (iii) what are the perspectives of Islamic economy that will be put forward in order to develop the concept of Sustainable Development?

In this study, because the Islamic economy has an understanding of the future, it will address the inequalities in income distribution and the strategies that will be put forward for the formation of sustainable development understanding, which will meet the needs of everyone and all segments and will provide answers to a more livable life expectancy.

In order to approach the injustices in income distribution and sustainable development strategies from the perspective of Islamic economy, it is necessary to put forward political stability on this issue, to revise the ideas put forward to date, to present complementary proposals by identifying missing aspects of current developments and to identify the current threats and opportunities. This study will reveal the social vision of the Islamic economy by addressing all aspects of income injustice and sustainable survival strategies.
\end{abstract}

a Res. Asst., Süleyman Demirel University, muhammetyurtseven@sdu.edu.tr

b Asst. Prof., KTO Karatay University, kamola.bayram@karatay.edu.tr 
Keywords: Islamic Economy, Sustainable Devolopment, Islam, Injuctice, SD Goals.

\section{淡济 \\ SOSYAL ADALETSIZLIIKLERIN AZALTILMASI VE SÜRDÜRÜLEBİLİR KALKINMA HEDEFLERİ AÇISINDAN İSLAM EKONOMISINININ ROLÜ}

Gelecek nesillerin ihtiyaçlarını karşılayabilme olanağından ödün vermeksizin günümüz neslinin ihtiyaçlarını karşılayabilecek bir kalkınma modeli olarak ilan edilen sürdürülebilir kalkınma hedefleri (SKH), 20. yüzyıl sonlarına doğru dünya gündeminde yerini almış ve 1990'lı yıllarda imzalanan uluslararası antlaşmalarla küresel bir uygulama planı haline gelmiştir. Küresel anlamdaki sosyal adaletsizlikleri azaltma, yoksullukla mücadele ve sürdürülebilir bir refah anlayışını dünya geneline hakim kılma, eğitim, çevresel ve ekolojik sorunlarla mücadele etme gibi bir çok insani hedefi amaçlayan bu politikalar ilk dönemlerden itibaren ilgi uyandırmış ve bir çok devlet tarafından da politika aracı olarak kullanılmıştır.

Küresel düzeyde varlığını sürdüren sosyal adaletsizlikler ve kat kat artan gelir eşitsizlikleri ile yoksulluk oranları günümüz dünyasının karşılaştığı en ciddi sorunlardan birisi haline gelmiş ve sürdürülebilir kalkınma politikalarının işlevi tartışılmaya başlanmıştır. 1980'lerle başlayan hızlı değişim süreciyle birlikte gelir dağılımı sorunu sıradan bir ekonomi sorunu olmaktan çıkmış politik ve sosyal bir sorun olarak algılanmaya başlanmıștır. Dünya ölçeğinde 1950'li yllardan itibaren uygulanan ve günümüzde de değişik boyutlarıyla sürdürülmeye çalıșlan SKH var olan adaletsizlikleri, yoksulluğu ve sosyokültürel sorunları daha da belirgin hale getirmiştir iddiasıyla birçok eleştiriye maruz kalmıştır.

[Türkçe geniş̧ öz çalış̧manın sonunda yer almaktadır.]

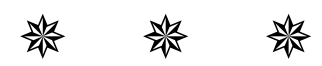

\section{Introduction}

According to the dominant paradigm defining the societies living in the world, when "developed, underdeveloped, and developing" concepts are taken into consideration, one can see that the majority of Islamic countries in the category of developing countries (United, 2016) Therefore, it is necessary to redefine the concept of development and the relationship of Muslim states with this concept. Although the reality of countries in this category is exposed to a number of factors that hinder development, such as colonial, civil war, geographical location and demographic differences in terms of political history, we must focus on whether development policies and social justice are established (Macit, 2005, pp. 67-68). 
While poverty continues to be a severe problem throughout the world and especially in Islamic countries, the world we live in has become an inexorable place due to political and moral deterioration. The world economic system, which is centralized in the focus of social and ecological imbalances, has come to a stage of severe stagnation and collapse due to a global crisis that cannot be overcome despite intense efforts. Although the concept of development strategies and sustainability was introduced 30 years ago due to social, ecological and economic crises, it failed to solve the problems of humanity and crises (Harding, 2006, p. 229; Sneddon, Howarth, \& Norgaard, 2006, p. 256).

The concept of development aims not only economic growth, but also the betterment of the quality of life of all humanity, improvement of the standards of life, to ensure that all people have equal access to resources, conscious environmental understanding, ecological balance, education and health. Sustainable development is to consume the resources of humanity in the world consciously and to respect the rights of future generations and to establish a balanced lifestyle (Seyidoğlu, 1999, p. 580)

The concept of sustainable development, which was included in the "Our Common Future" report published in 1987 after the studies of the World Commission on Environment and Development (Brundtland Commission) in 1987 for the first time in the historical process, has been published within the framework of the United Nations' program and target reports has gained a global dimension with international conferences (IMF, 2016; United Nations, 1987)

While studies in the fields of development, sustainable development and social justice have increased in the Western world, the interest in this issue in Islamic societies is unfortunately not very encouraging. In this study, the concepts of enrichment, progress, growth and development will be examined in general terms within the framework of the views emerging from the history of economics. Then the approach of Islamic economic thought to these concepts will be highlighted.

Besides, the process of transition from the concept of development to the concept of sustainable development will be discussed, and a general evaluation will be derived. The theoretical and practical aspects of sustainable development objectives, what are the objections to sustainable development objectives in terms of Islamic economy, and the relationship between the accepted objectives and current practices will be examined. Finally, the scorecard and current status of the SC objectives in terms of 
social justice will be presented.

\section{A. Conceptual Framework of Social Justice}

One of the most common definitions expressing the framework of social justice is the regulation of the relationship of the social individual with other members of the society to realize the common good in general (Miller, 1999). However, the concept of social justice is a modern and new concept which traces its roots back to the 19th century and was not studied by pioneer philosophers such as Aristotle, Plato, Ibn Rushd, Kant, Rousseau in historical thought, as justice, injustice, law and equality are discussed or studied. The concept of social justice and its negative form, social injustice, first emerged with the political language that developed after the industrial revolution and became an objection to the exploitation of capitalist labour and a focus for the improvement of humanity - the human condition. In the literature, by Proudhon, justice has been identified with social justice and social justice with human dignity (United Nations, 2006, pp. 11-12).

Those who advocate the elimination of injustices in the society through a change of order (Radical Social Justice Movement) by associating it with the concept of justice, tried to establish social justice through the state. On the other hand, justice was defined through the establishment method, for example, Nozick's "pure market justice", which prevent state intervention, Hayek's "market justice" that allows limited state intervention, and Rawls' "distributive justice" that gives the state an important role in the intervention. (Hayek, 1978, pp. 58-59; Nozick, 2001, p. 84; Rawls, 1999, pp. 542-544). Furthermore, in the above doctrines, equality is the basis of justice initiatives. In particular, distributive justice differs from regulatory justice in terms of equality. The basic approach of distributive justice is that individuals in society assume a role in life according to their capacities and receive the remuneration of this status according to the principle of equality. However, it should not be forgotten that the equation here is explained with economic gains. Since the income obtained by the settled order brought by the market economy and the division of this income among individuals was not found sufficient in terms of rationality, the distributive justice theory was developed, and it was aimed to achieve equality with this theory (Kurt, 2006, p. 206).

While social justice, which is explained through justice, the welfare state and the social welfare state, deals with the distribution of resources in the society in a narrow sense, it deals with the extent to which the resources and services produced for individuals living in the social reach and equality 
of opportunity in this regard, which implies the elevating justice from being a mere discourse and putting it into practice in a social sense, which concerns the practical field (law-economics) rather than theory only (Barry, 2017, pp. 15-17).

On the political level, where social justice is associated with the existing and social injustice with the neglected, it is expressed as a reflection of income distribution or development and has been discussed in the literature by making a national/international or individual / state distinction, sometimes it has been discussed in a purely economical sense and sometimes with its multi-faceted structure (Er, 2006; Kuçuradi, 2011). It is also stated that social-economic theories such as the welfare market and consumer welfare can only be realized on a ground where social justice is ensured(Sirgy, 2008, pp. 207-208). The possibility of unfair societies to establish social justice and the fairness of societies where social justice is not realized will be on the same plane and will be exempt from social benefits (Jafari \& Sandıkcl, 2015, p. 60). While the elimination of social injustice at the international level is seen almost as a problem for many different reasons, it seems possible to be remedied at the national level (Kuçuradi, 2011, p. 13). However, it should not be forgotten that what constitutes the possibility of social justice is not space and time, but a fair social structure. According to Fârâbî, a just society may be possible with the combination of justice and virtue (Fârâbî, 1980, pp. 43-46).

\section{B. Projection on Social Injustice}

The history, which has witnessed the brutal life under the shadow of justice, has carried its own sovereignty, which it has built on the other since the medieval, to the present day with many discourses and slogans and has always survived by constantly changing its formal appearance without losing its cruelty. For example, those who introduce geographical discoveries as the key to great scientific developments for humanity do not show the brutality full of injustice in their background. Before the discoveries, people who live in freedom and prosperity in their own lands were brutally deprived of their freedom and well-being, and their religion, language, and culture were forcibly changed with the arrival of white people. Those who resisted this coercion were slaughtered, and those who submitted were enslaved (Casas, 1999). Rousseau expresses the brutality of the rich in subjugating individuals in society as follows;

As soon as the rich tasted the pleasure of ruling their share, they began to belittle all other pleasures; While using their old slaves to 
subdue new slaves, they think of nothing but making their neighbours servants. They were like hungry wolves who once tasted human flesh, refusing all other food with gruff, only wanting to swallow humans (Rousseau, 2017, pp. 137-138).

Capitalist societies usurping the future of free peoples by taking their colonial power behind them were not only an attitude in economic terms. Especially after the 18th century, the prevailing attitude was that the poor should never get rid of poverty, and the new generation should not dream of a future beyond the plough or loom. This approach was the main motive behind the failure of economic theories based on labour and incentives (motivation) and their result in the exploitation of labour, which is regarded as the most valuable property of man. Another reason was that for the continuation of Christian ethics, the poor in society and the rich helping these poor as a religious duty was perceived as a theological ritual. Therefore, the continuation of poverty was a prerequisite for preventing the deterioration of social hierarchy and for the continuity of Christian theology (Fleischacker, 2013, p. 127).

When it comes to the 20th century, the concepts of developed, developing and the underdeveloped state as a political discourse constitute the most obvious example of the polarization of the world and the legitimization of a subordinate language with politics and policies. Due to the endless ambitions of the capitalist states, they spread beyond their own nations to other geographies of the world to expand their production and market networks. As a result of this wild spread, they made efforts to allocate cheaper labour and more people's future due to their competition with their rivals (Beaud, 2016, pp. 189-191).

When we look at the capacity of the dominant economic thought to make people reach happiness, the scientific and epistemic definitions that are made with the aim of increasing the satisfaction of humanity by dividing the scarce resources available in the world to limitless human needs will easily be seen (Görmüş, 2015, p. 162). According to the OECD's 2012 report, the unfair distribution of income (Gini coefficient) in the world between 1980 and 2010 increased by $10 \%$ and the gap between the rich and the poor became even more pronounced (OECD, 2012). Wealth inequality among individuals has continued to improve day by day since 1980, especially in countries where capitalist reforms were implemented (Wid.World, 2018). For example, in the ranking of states with the highest income inequality, |116| China ranks 1st, the USA ranks 4th, and Israel ranks 5th (OECD, 2012). While the researches and the reports revealed the gravity of the situation, many 
different classifications have to be brought to the definition of inequalities, especially poverty, in the literature (Erdem, 2003).

The Problems in the definition and the flaws of the system built on this definition made many other corrective programs mandatory, and the discourse and projects of the dominant paradigm never left the market empty. Based on their description, it is seen that they try to put into effect many projects such as Sustainable Development Goals (SDGs) to reduce them by saying that poverty and injustice are a normal situation. If the usual economic activities continue, global inequality and poverty will increase even more for the 2050 vision (Wid.World, 2018). This dominant paradigm put forward with Adam Smith considered wages against labour, interest against capital, rent against the land, and profit against the entrepreneur as appropriate and within this framework has developed countless policies to the date.

According to the 2019 Global Multidimensional Poverty Index, the striking picture of social injustice around the world has been presented and according to the findings, it has been stated that while the high-income living level has not changed, a serious transfer from the average living level to the lower-income level of life is continuing (UNDP, 2019). While 1.3 billion people are exposed to multidimensional inequality worldwide, 2 billion people are struggling with poverty.

Sub-Saharan African countries and South Asia constitute regions where multidimensional social injustices cluster. The proportion of those living in this region who are exposed to multidimensional inequalities to the world is $84.5 \%$. For example, the multifaceted inequality rate on a national basis in South Sudan, which is located in this region, is $91.9 \%$. Multidimensional inequality rates differ from country to country, as well as by variables such as rural life and urban life, adult and children, women and men. For example, the multidimensional inequality rate in children is twice as high as in normal adults, and children around the world suffer from inequality. In Chad, Ethiopia, Burkina Faso, Niger and South Sudan, around $90 \%$ or more of children under 10 are multidimensionally poor (UNDP, 2019).

From the point of view of the deficiencies of the definition, according to Imam Ghazali, economics is the knowledge of using relatively scarce resources in a way that will increase the welfare of the whole humanity without creating any injustice and environmental problems within the rules of Shariah, and this understanding of fair distribution is the most critical 
motivation of Islamic economics in reducing social injustice (Orman, 2016a). From the general point of view of Islamic economics, as a manifestation of the attributes of Allah's er-Razzak and Generous, it is also able to meet the needs of the people in the world, and the resources are not unlimited. The scarcity of resources is related to either people's inability to reach those bounties due to lack of information or problems due to excessive greed and consumption. The problem here is the injustice of the rich due to excessive greed and consumption (Zaman, 2008).

The fact that the human model designed within the dominant paradigm is rational and wants to maximize its benefit at all times and under all conditions prevents from the very beginning to think of another and become an altruist. However, according to the understanding of Islamic economics, Human beings, whose boundaries are drawn by Allah, have an attitude to fulfil their needs while being just, not wasting, thinking of others, cooperating with others and possessing a social responsibility consciousness (Zâim, 1995). Besides, within the prevailing paradigm, private property has priority over the right to live, and all kinds of aid, donations, unrequited assistance and zakat are never accepted to reduce ownership (wealth). Even property is considered sacred, and people have been directed to accumulate and increase continuously. As a result, property and wealth were concentrated in the hands of a certain group and a serious income injustice occurred between the rich and the poor within the society.

Social justice is not a phenomenon that can only be realized through the fair sharing of "things". It is a concept that can be established by distributing all kinds of needs that will enable people to live in a way that is worthy of human dignity (Kuçuradi, 2011). The mechanism that will establish social justice in the Islamic tradition has been put forward by the theory of purposeful human rights, and the religion, mind, life, property and generation of people are protected. The potential of these five fundamental principles that will allow humane living has been private as the typical call of all prophets sent by Allah and has gained a universal dimension by being adopted by the Islamic tradition (al-Ghazali, 1988, p. 288).

C. Evolution of Development, Growth and Progress in Economic Thought (Mercantilism, Physiocrasy, Classical Economic, Capitalism, Neo-Classical)

Since the day of creation human beings are working to meet their needs. They worked as a gatherer and hunter to meet these needs. Later, they meet needs by dealing with agriculture. With the accumulation of savings, 
the process of industrialization was started and the old necessities were gradually abandoned and industrial activities have started. Subsequently, industry and industrial activities alone were not sufficient and new actors were needed. Together with many actors such as information technology, innovation and high technology, people continued to meet their needs. In all these processes, we see that the concepts such as enrichment, growth, progress and development have evolved and changed according to (Yavilioğlu, 2002, p. 59).

Since the beginning of the 15th century, when economic thought was systematically dealt with, almost every trend of economic thought approached these concepts in different ways. This process that started with Mercantilism continued with the Physiocrats and by the 18th century it was redefined by Classical economic thought. The criticisms of Classical economic thought and the post 1929 Great Depression were then re-examined by Marxist-Capitalist thought. This redefinition process continued with Schumpeter, the founder of innovative economics, further diversified by Keynes, and identified by additional factors by the Neo Classicalists. This was not enough and today many economists are trying to put forward different definitions and views on this issue. After briefly analyzing these views in our study, we will try to examine the views of Islamic economics which will be included in today's definitions (Savaş, 2000, pp. 138-139).

According to Mercantilism, which was at the center of the European economic thought system between 1500 and 1800, the focus of growth, development and enrichment was precious mine-based trade. During this period, which was named as the age of explorers, the precious metals obtained through colonial activities comprise the main capital. The trade of these precious mines created a source of wealth and was constantly encouraged by patronizing state policies. Growth and progress can be mentioned in terms of volume of commercial activities (Kazgan, 2004, pp. 43-48). According to this understanding, which is also known as commercial capitalism, the acquisition of the necessary minerals for trade, taking restrictive measures through the state channel in commercial and industrial activities, the balance of payments and seeing the interests of the country above all in international competition constituted the basic dynamics of this idea (Özsağir, 2008, p. 3). The common point of the founding ideas of Mercantilism, which was found tobe incompatible in theory and practice, was that precious metals were seen as the only measure of wealth, progress and development. From this point of view, wealth increase, i.e. enrichment, can be achieved by obtaining precious metals. W. R. Allen "foreign trade creates 
wealth, strength in wealth, with this force, we protect our trade and religion" and expressed the essence of mercantilist thought (Savaş, 2000, p. 139). In this system of thinking, the functions and functions of the state are very important. Growth, development and enrichment activities are carried out indirectly by the government. In other words, it is seen that merchants and sovereigns are in close relationship since economic wealth refers to the wealth of both the economy and the state. The precious metal, the only criterion of wealth, must remain within the borders of the country. So the balance of foreign trade should be positive and the treasury should be strengthened. In order to achieve this, the government should take measures to reduce imports and increase exports (Kazgan, 2004, p. 45)

According to the thought system that we tried to summarize above, the criterion of progress, growth, development and enrichment is indexed only to precious metals and wealth is measured as much as the substance owned. Concepts such as production, distribution and social justice have hardly been mentioned. This idea, in which poverty was considered as an opportunity to gain wealth, was also the basis of the Capitalist thought system (Figure 1).

Figure 1: Mercantilism Thought System and Results

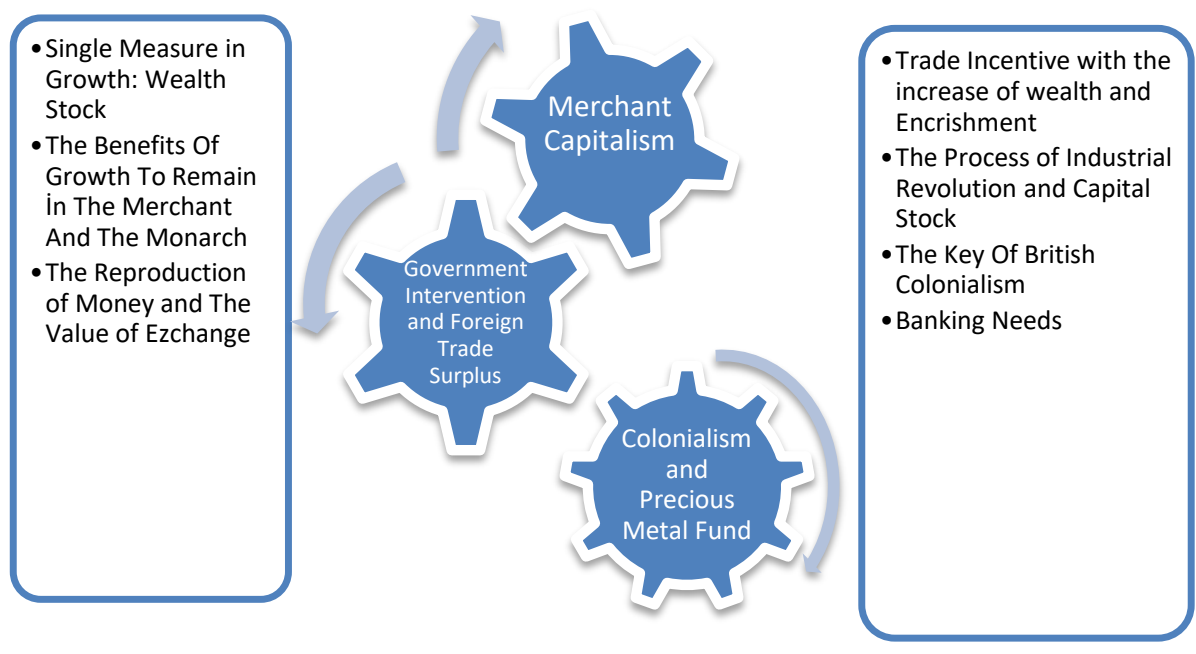

Source: Inspired By The Author Adam Smith's Book The Wealth of Nations

According to this system of thought, which was put forward by the French reformers as a reaction to Mercantilism, which carried out research on wealth and production, they aimed to establish an economic system based on production since trade enrichment would not be enough. They tried to form an economic model by adopting policies based on farming, fisheries, mining and agriculture based on the fact that the aid of the land is inevitable 
for trade to provide enrichment. Physiocrats, who believe that a trade based on production, rather than a trade based on exchange, will enrich and develop the country, giving importance to agriculture as the dynamic factor of growth. They predicted that the state would not intervene in the economy and that the market would operate with a natural order. The main objective at the end of production is to generate the residual value (Figure 2). They called this theory circular flow. In other words, they have adopted a sustainable growth policy by obtaining more of the raw materials included in production as a result of this production. This reveals the interest of agricultural capital earnings (Kazgan, 2004, pp. 56-58)

They predicted that the source of wealth is the net product. They divided society into certain classes in the light of the policies adopted in this way. The main reason for this categorical distinction is adopted as landowners, farmers, traders and industrialists. As a result, the only criterion for growth and development is output. Therefore, it has been criticized by many economists (Savaş, 2000, p. 230)

Figure 2: Circular Flow in Physiocratic Economic Thought

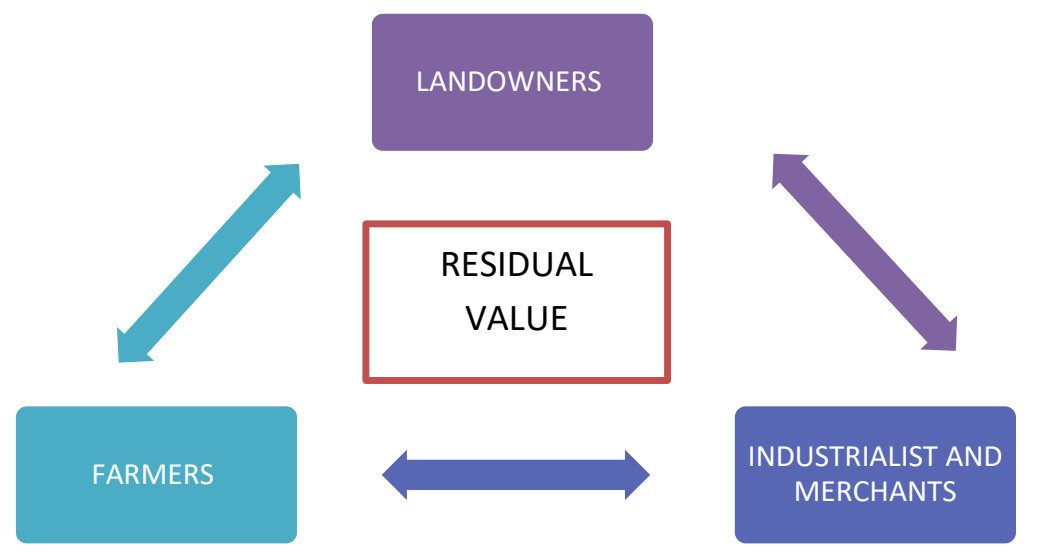

Source: Inspired by the author Karl Marx's book Das Capital, Volume II: The Critique of Political Economy.

This movement of thought, which was influential in the last quarter of the 18th century and in the 19th century, made the concept of labor force the focal point, arguing that only the capital flows were not sufficient against the concept of output which is the sole basis of the growth of Physiocrats. They did not accept the assumption of continuous growth as in Mercantilism and Physiocracy, and expressed that there would be a period of recession in the economy after growth. They also stated that the phenomenon that is effective in growth would not be realized with only one concept, but also played a vital 
role in technological developments and social factors.

According to them, the goals of the theoretically revealed factors have not been realized and different theories have begun to be produced against the real situation. Adam Smith mentions progress rather than development. For example, he explained Britain's industrialization process with progress, not development. He also linked the material progress to the accumulation of capital and this accumulation to the tendency to raise money in the wealthy class (Smith, 1982, pp. 276-280). In addition, until the World War II, almost all economists have been explaining the concept of material progress as the concept of development (Yavilioğlu, 2002, p. 60)

On the other hand, the other factor that attracted attention in this period was the population. According to classics, population is one of the most important indicators of growth. The thesis that the resources available against the increasing population will not be sufficient has been frequently brought up. Therefore, a paradigm taking into account the dynamics of the population has been proposed. Both A. Smith and D. Ricardo could not explain the growth of developed countries as a model in their growth theories. Their theories for the underdeveloped countries are in conflict with reality. On the other hand, the growth model which they put forward as decreasing yields and increasing yields law has a systematic understanding of labor and capital (Figure 3). However, it was not a real successful model.

Figure 3: Ricardian Growth Model

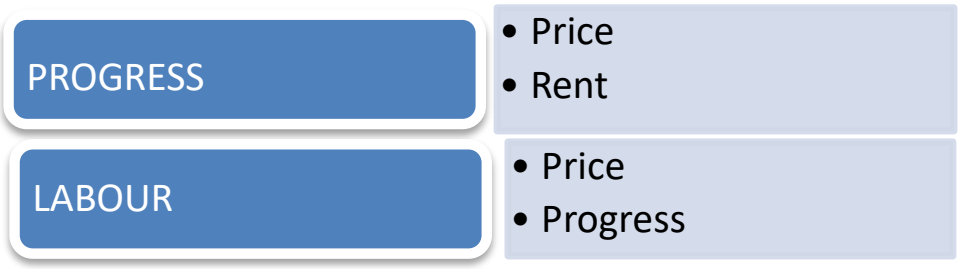

Source: Inspired by the author Halil Seyitoglu's book Uluslararası İktisat

This idea, which has been cored by Karl Marx and has been valid in the world market since the 19th century and has been adopted by many countries, comes to the fore with the theory of labor-value and surplus-value. In fact, the main reasons for putting forward these and similar theories are International instabilities, changing balances after the first and second world wars, competition based on colonialism and economic crises occurring worldwide. In this system of thinking, the most important factor that determines the growth is capital "Capital". Capital is the transformation of surplus value into Capital. 
In this view, it is aimed to seize labor, to take control of natural resources and thus to keep the market under control. While establishing this, the state structure was used as the most important tool (Figure 4). The state administrators who cooperate with the community leaders have established a brutal system by keeping the capital accumulation produced by the people away from the public (Chapra, 1995, p. 72).

Figure 4: The Pyramid of Capitalism (Issued by Nedeljkovich, Brashick and Kuharich, Cleveland: The International Publishing Co., 1911)

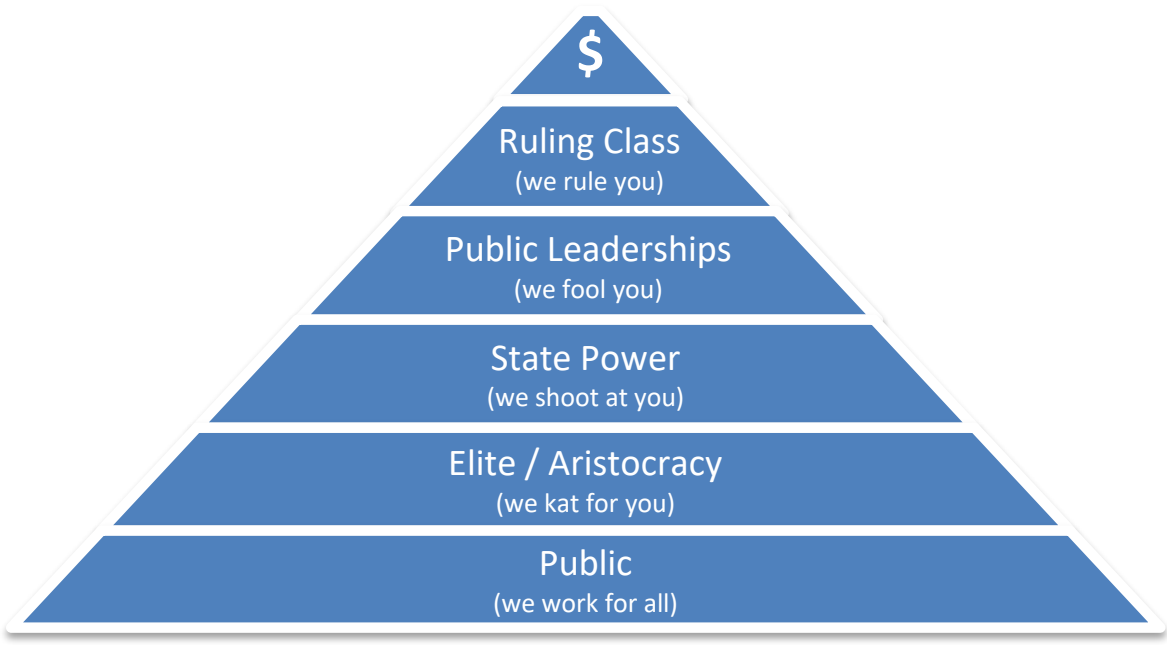

In the world economic system, especially from the 20th century, many reflections of this system of thought reach to the present day. In particular, the accumulation of capital and the dominance in finance have enabled many economic factors to be realized on these foundations. When we look at the last century of this system (Graph 1), we can see the stability of growth clearly.

Graph 1: World Economy Growth Stability (1961-2015)

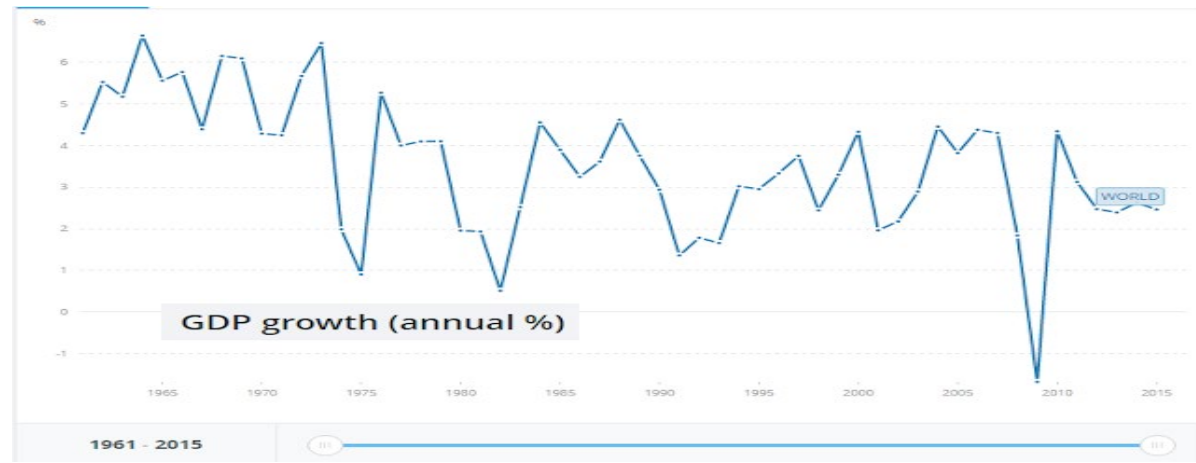

Source: (IMF, 2016) 
Innovative economics, which determines growth and development according to other material and immaterial factors, determines labor and capital as material; they considered technological and social development as an intangible factor. Adopting an innovative economic model, Schumpeter stated that the economic growth will be achieved through innovations in goods, production techniques, market, input and organization factors. In a capitalist model, he stated that growth by the entrepreneur would find space in the social and technological sense and predicted that the determination of a method form that would allow the formation of entrepreneurs would increase the speed of growth. He said that the more entrepreneurs are created, the more growth will take place (Schumpeter, 1936, pp. 701-795). It can be said that the concept of innovation with the understanding of entrepreneurship and innovation entered the economic literature with this idea (Figure 5).

Figure 5: Schumpeter Economic Growth Model

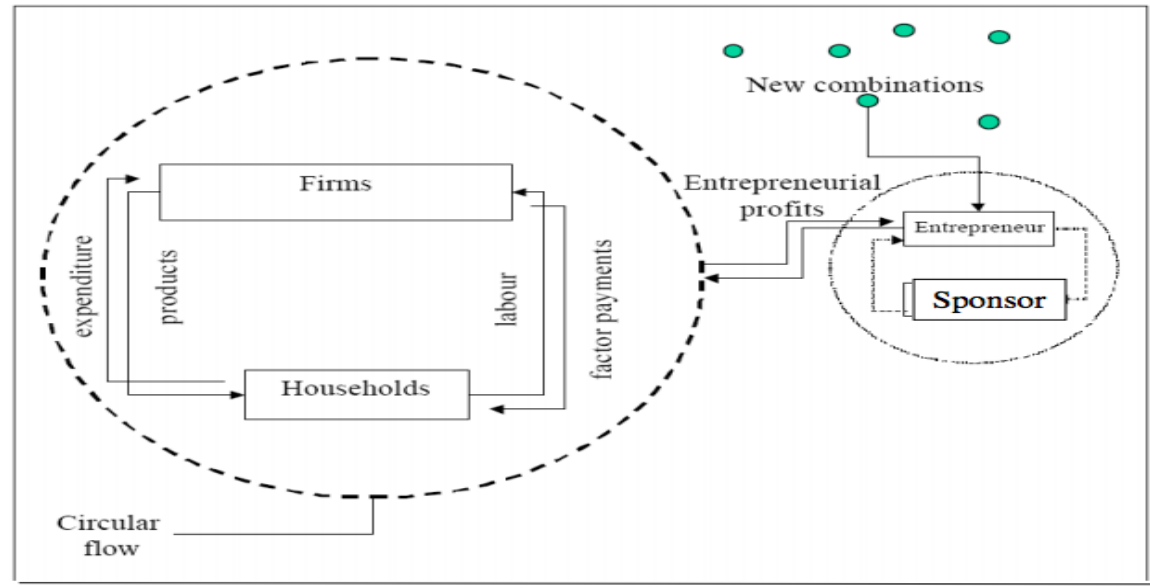

Source: Inspired by the author Aubrey Poon's artichle A Comparison of the Theories of Joseph Alois Schumpeter and John Maynard Keynes

John Maynard Keynes, who put forward theories on how to overcome world crises and economic stagnation, published his book titled "The General Theory of Employment, Interest and Money" in 1936 following the US economic crisis of 1929 and his thoughts on the following principles. It was steadfast. An interventionist understanding of the state argued that, except in the usual cases, employment in the economy is complete, each supply will create its own demand, the balance will occur by increasing public services and decreasing taxes and thus, increasing commercial transactions and encouraging households to spend (Smithies, 1951, pp. 163-169). The Horrod 
Domar model, which was created after the idea of Keynes and inspired by his ideas, stated that the capital created by savings and savings in the economy would be spent on investments and that increasing capital would result in increasing investments. It has been stated that this capital accumulation will bring about rapid economic growth (Figure 6).

Figure 6: Harrod-Domar Growth Model

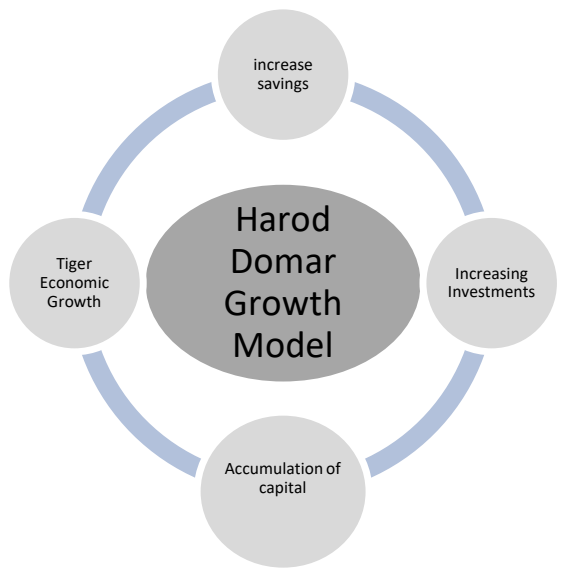

Source: Inspired by the author R. F. Harrod's Artichal An Essay in Dynamic Theory

Adopting a closed economy model, defending competitive market conditions, seeing economic behavior as rational, decreasing for production, capital and labor; for the production function, this model advocates a constant return and envisages a comprehensive model including technological developments and population factor (Figure 7). The Solow model envisions the balance of investment and technological developments and labor as the basic dynamics of growth and development (Chapra, 1995, pp. 167-169). Solow also stated that the main difference between the two countries is dynamic and rapid population growth is not a good situation for economic development and per capita growth rate will necessarily occur with technological developments. After neo-classical thinking, technological developments and innovative activities have shown a rapid increase compared to previous periods and caused a serious questioning of previous ideas (Karakayalı, 2010). According to Neo classics, these factors are external and it is understood that there are factors affecting growth and development besides those owned. 
Figure 7: Solow Development and Growth Model

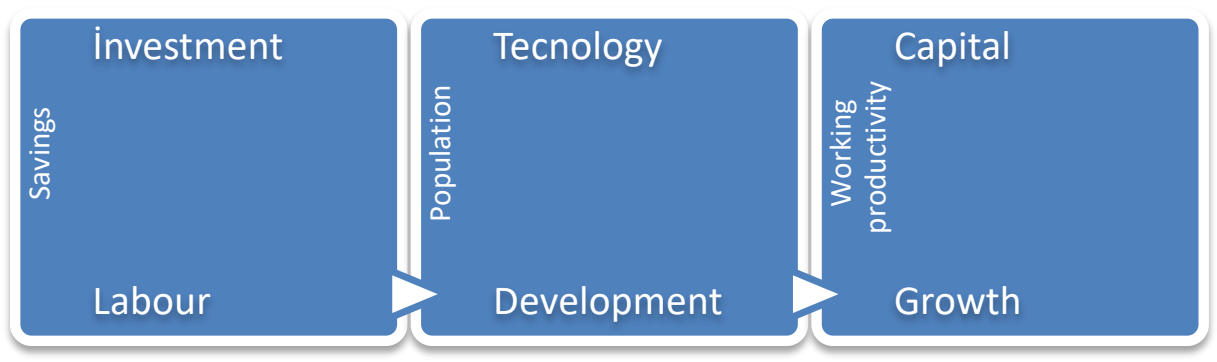

Source: Inspired by the author Karakayalı's Book Theories Growth and Development (Karakayalı, 2010)

We tried to summarize the historical adventure of Growth and Development in the above section. Neo-Classical thought theories that we can accept as the last period thinking about growth and development have not been accepted and alternative searches on this subject have continued. The search for new models is based on micro foundations. It is seen that other factors are added to the factors affecting the traditional growth and development (Romer, 1986, p. 1005). Romer, one of the most important figures of this idea called new growth or internal growth theory, accepted technical knowledge as an internal factor and explained the production input as cost-free. Together with Romer, knowledge has become the focus of growth in economic literature and has caused capital to lose its relatively superior position. The fact that capital is depleted as it is spent and information is valuable as it is spent increases the belief that investments should be made towards this field, contrary to previous ideas about growth.

Another contributor to this method was G. Lukas. The most important element that stands out in Lukas is the concept of human capital. In addition to physical capital, human capital is also a major factor in growth and development. Japan and Germany are examples of rapidly growing economies with human capital. The emergence of the concept of $\mathrm{R} \& \mathrm{D}$, the importance of investments in technology and the increasing interest in information sources have changed many traditional ideas. Recently, in addition to these factors, public goods, communication and information movements have gained significant importance. Whether these factors, which are one of the necessities of the age, are integrated into the economic system as a whole, directly affects growth. Thus, the transition from the industrial economy to the information economy, unqualified labor and the importance of dry capital decreased, and instead, increased information technologies and information investments came to the forefront (Lucas, 
1988). In summary, today's development and growth methodology, human capital investments and R \& D activities are combined with other factors predominantly, transferring the accumulated knowledge to the needed areas with the support of the state infrastructure and an increase in productivity has been achieved (Figure 8).

Figure 8: Post-Neo Classical Growth and Development Model

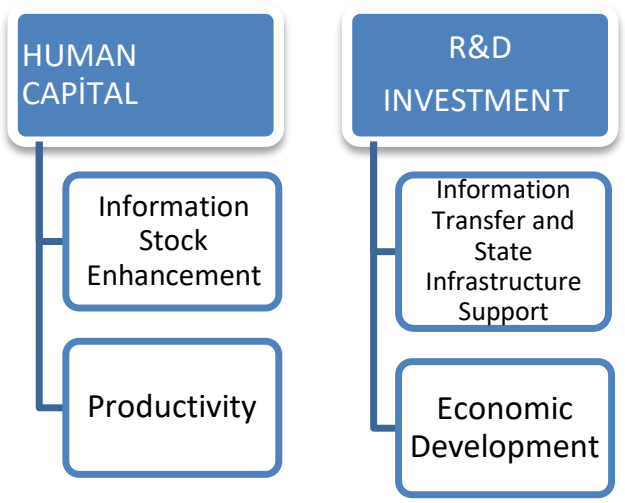

Source: Inspired by the author Lukas and Romer's artichles(Karakayalı, 2010)

\section{Current Status}

Development and its derivative concepts have been the most important areas of interest in the world economy from the beginning. From the beginning of the World War, it has become an official policy on the basis of countries. While the speculative meaning and controversy that these concepts contain is still ongoing, the methodological criticisms and real situation directed to it in recent years have made the intricate structure of development even more complex. Full employment, economic stability, equal distribution of resources among individuals and tremendous targets such as fair income distribution constitute the basis of development policies and the fact that growth in the GNP rate is placed at the center is accepted as the main parameter of the emerging problem (Peterson, 1994, p. 481).

The mainstream theories that growth will always benefit employment and support stability will often be mentioned. The imbalance between growth and distribution was regarded as the sole basis. In addition, the extreme imbalance in developing countries has become a serious problem. Therefore, it was meaningless to talk about equal distribution, stability and employment without growth. There was also a serious expectation that this problem would be overcome by growth. Namely; The growth in income during the distribution process would gradually spread towards the lower ranks of the society and this benefit, which emerged with industrialization in 
the following periods, would expand and reach all segments (Hasan, 2006).

Graph 2: Growth rates of world countries between 1900 and 2019

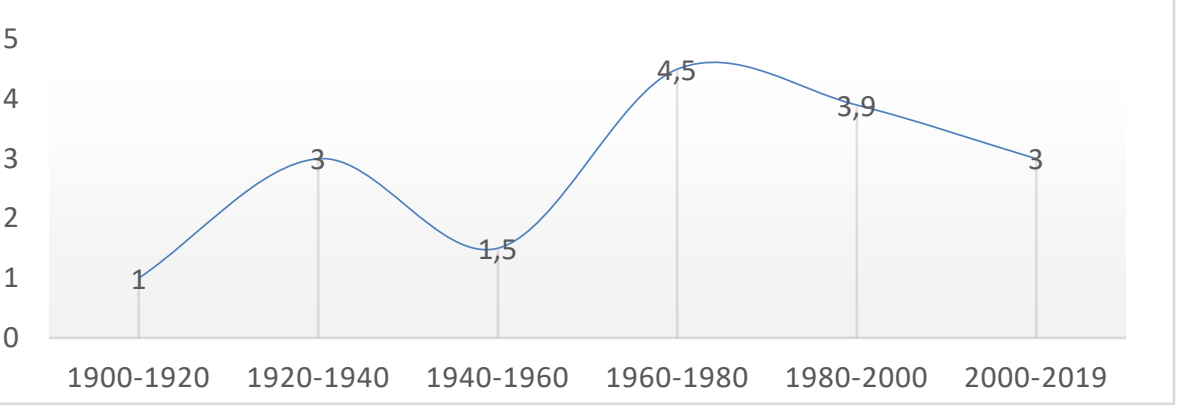

Source: (IMF, 2016)

As it can be seen from the table above, the GNP-based growth targets of developing countries have been put into practice rapidly since the 1950s and unilateral growth targets have been largely achieved (Chart 2). This was much faster than the growth rate of developed or developing countries in any period before the 1950s. The world has become rich, has grown gradually according to the GNP and the target has been achieved. However, all the paradigms and theories about growth are only reflected in the GNP rate. In the enriched world economy, the gap between the rich and the poor has been opened both between individuals and on the basis of states. While the real situation differs so much from the indicators in terms of economy, the ecological balance has also been subjected to a terrible disruption. Rapid developments and industrial activities have led to the depletion of the ozone layer, global climate changes, the destruction of forests and nature, and the gradual decline of living diversity. Rapid growth has become increasingly catastrophic with environmental problems, particularly poverty and social injustices, rather than an advantage (Kaypak, 2011; Tiraș, 2012, p. 23).

Table 1: Worldwide GDP Per Capita (in USD)

\begin{tabular}{llllll}
\hline REGION & $\mathbf{1 8 8 0}$ & $\mathbf{1 9 1 0}$ & $\mathbf{1 9 5 0}$ & $\mathbf{1 9 7 0}$ & $\mathbf{2 0 1 9}$ \\
\hline West Europe & 1.960 & 3.457 & 4.578 & 11.417 & 19.912 \\
\hline ABD, Australia, New Zeland & 2.419 & 5.233 & 9.268 & 16.179 & 28.039 \\
\hline Asia & 556 & 969 & 717 & 1.718 & 4.434 \\
\hline Latin America & 676 & 1.494 & 2.503 & 4.513 & 5.786 \\
\hline Eastern Europe, SSCB & 941 & 1.558 & 2.602 & 5.731 & 5.705 \\
\hline
\end{tabular}


The Role of Islamic Economy in Reduction of Social Injustice and Sustainable Development Goals

\begin{tabular}{llllll}
\hline Africa & 500 & 637 & 890 & 1.410 & 1.549 \\
\hline $\begin{array}{l}\text { Highest Difference And Lowest } \\
\text { Difference }\end{array}$ & $5 / 1$ & $8 / 1$ & $13 / 1$ & $12 / 1$ & $18 / 1$
\end{tabular}

Source: J. Bolt and Van Zanden: The Maddison Project

These global indicators of income distribution (Table 1) tell us nothing but inequality. The richness, growth, development and progress activities that started with industrialization revealed many utopian paintings such that humanity facilitates and enriches life, increases the quality of life, and increases the need for labor by increasing resources. However, it is a fact that the income gap between different regions of the world has increased. For example; While the income of the richest countries was three times that of the poorest countries in the late 19th century, this figure increased 15 times in the middle of the 20th century and has now reached 21 times (Emin, 2016, pp. 32-35).

This income imbalance also brings about many social problems. It negatively affects human life by revealing negative situations in many subjects such as health, education and social expenditure which are necessary for the continuation of human life. As a result, vicious cycles are seen in the life of a society where social justice cannot be established (Figure 9).

Figure 9: Vicious Circle of Income Inequality

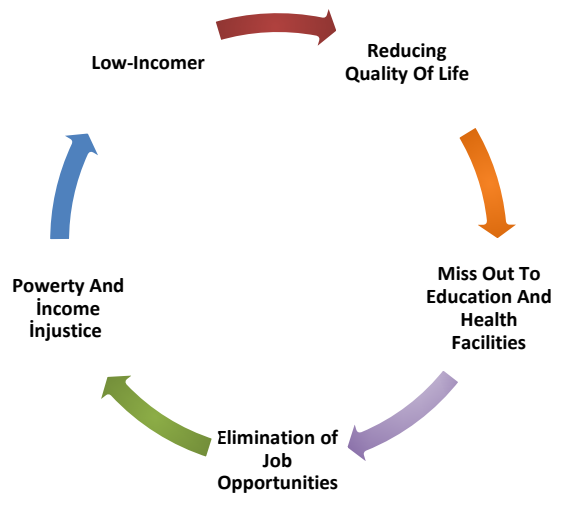

Source:(Emin, 2016, p. 32)

\section{E. Literature Review}

While the global market share of Islamic finance in developed countries is $7 \%$ with 2.4 trillion dollars, the market share in less developed countries is around $34 \%$. In 2023, this volume will grow even more when 
this volume reaches 3.8 trillion dollars. In this respect, the potential of applying Islamic financial practices in underdeveloped countries where social injustice is ordinary is more substantial (TheCityUK, 2019).

Within the framework of the SDGs, many issues such as the human and physical capital potential of Muslim countries, financial size in the Gulf countries, historical experience and accumulation from their past draw attention and especially the density of the young population is seen as an essential opportunity for SDG realization (Ahmed, Mohieldin, Verbeek, \& Aboulmagd, 2015). The attitude of Islamic thought and Islamic worldview against social, economic and environmental difficulties and the synergy it will put forward in this context is a phenomenon that is not utopian but reciprocated with social finance institutions. With social projects and programs that are not directly for profit but have serious social importance, it is discussed how and how this synergy can be created, and solutions are offered with many applications (zakat, foundation, microfinance) by mobilizing the potential funds available in its geography (resource mobilization) (Ismail \& Shaikh, 2017). In the case of Islamic finance mobilizing resources in the modern sense, the potential of realizing 11 of the direct SDGs has also been demonstrated with its current practices(Gundogdu, 2018). The current commercial practices of Islamic economics in establishing social justice and reducing social injustices have been examined, and the existing potentials of financing instruments (microfinance, qard al-hasan, zakat, waqf based financial instruments) to reduce poverty and increase rural development in the context of countries proved to be applicable (Abdalla, 1999; Osman, 1999; Sadr, 1999). For example, the current practices of Islamic fintech companies, which have recently become widespread in the Islamic finance industry, encourage increasing entrepreneurship by financing underdeveloped sectors such as agricultural enterprises and SMEs in Indonesia. In addition, it is seen that these companies collect funds such as donations, charity, and zakat and distribute them to the needy with a sense of social responsibility and carry out social projects for non-privileged individuals. Looking at these efforts, it is seen as directly synonymous with the goals of reducing poverty (SDG 1), fighting hunger (SDG 2) and eradicating social inequalities (SDG 10), which constitute the biggest challenge of the SDG goals (Hudaefi, 2020).

The institutional activities of the Islamic economy to overcome social exclusion, deprivation and poverty within the framework of the social protection base with the understanding of zakat are also drawing attention. For example, the role of Zakat funds in providing social protection in the 
Middle East and North Africa region has been examined in the example of Jordan and Sudan, and the findings have shown that the SDGs and the concept of zakat are fitting in an institutional framework (Bilo \& Machado, 2020). Maududi, who is accepted as one of the pioneers of Islamic economics, proposed an institutional reform by using the income distribution function of zakat as an alternative model for the fair distribution of welfare and contribution to social justice (Mawdûdî, 2014, pp. 83-90).

After the 2000s, the ideal-oriented Islamic finance understanding has started to develop commercial methods that include social responsibility in order to reduce the negative effects of dominant finance rather than commercial practices(Asutay, 2007, p. 16). In this context, they integrated the idea of microfinance with socially responsible investments and turned the lender into an Islamic microfinance idea based on musharakah and mudharabah partnership, which makes the lender responsible according to the work situation of the debtor and made it applicable in many countries (Askari, Iqbal, \& Mirakhor, 2008; Seibel, 2008).

It has been demonstrated that most of seventeen the development goals determined within the scope of SDG coincide with the long-term social goals of Islam and that the culture formed within the framework of the foundation understanding is a good opportunity to reduce development and social injustices, and the necessity of building the strongest social network of the Islamic economy on waqf foundations is emphasized. The social benefit and financial capacity created by the waqf-based activities carried out in Muslim countries have a capacity sufficient to meet both the "goal" understanding and SDG goals (Abdullah, 2018).

\section{F. Process of Transition from Development to Sustainable Development}

Although the concept of development emerged in the economic literature after the World War II, the concept of progress used in the same sense was used in the 13th Century began to be mentioned. On the one hand, the increase in labor and capital, thanks to the continuously developing technical knowledge and increasing natural resources; on the other hand, rapidly growing social, economic and political problems have started to take an important place on the world agenda.

The Wealth of Nations, published by Adam Smith in 1776, predicted an ever-increasing economic growth and the consequence that humanity would become more prosperous (Wallerstein, 1983, p. 78). While the policies carried out in accordance with these discourses continued to deplete the 
future of humanity, the report prepared by the Roman club in 1972 stated that unlimited growth was impossible due to limited resources (Visser \& Brundtland, 2013).

We have expressed the general views of growth, development, progress and enrichment in terms of economic considerations in the above sections. When we examine the ideas put forward in this regard, it is seen that the concept of development is only concerned with the economic dimension and other socio-cultural fields are neglected (Yavilioğlu, 2002, p.63). However, every emerging economic thought has been put forward either to complete a deficiency of its predecessor, to enrich it with additional ideas or to change it by showing that it is not functional or it has taken its place as an alternative. As a result, in the 21st century, the dimensions of the concept of development had to undergo a radical change in parallel with the dimensions of the changing sociology of the world. Thus, the concept of development and growth has not only had an economic dimension but has more important dimensions than the economy.

Since World War II, the enlightened masses in both Europe and America have become interested in economic policies of Asian and African countries and especially development problems. In order to prevent the existing problems in the world economy, the mentioned reason under this interest was introduced as the balance of the world economy by raising the economies of the less developed countries to the level of developed countries. However, most experts in this field know that the main reason behind this interest is to expand the economic markets of the more developed countries that they want to restructure and to create new demands. The need to reorganize the economies and markets that changed hands after the war was seriously crucial. In addition, the new regimes of the Asian and African countries, which demanded political freedoms by escaping from the order of exploitation, can be consciously considered as the other reasons of this increasing interest in the economic demands of the Western intellectuals (Hasan, 2006).

Many developments in world politics, and especially the modernization process, have replaced the traditional theories of the period with a global and dominant discourse. Universal concepts such as growth, progress, development and sustainable development (SD) have been gathered under a single initiative and became managerial. It has evolved into sovereign programs implemented by the strong states against the weak. This has led to the deliberate ignorance of many models applied in traditional 
times or in the history, or not being taken into account because they are not appropriate to the current understanding. Zakat institutions, foundations and microfinance studies in Islamic thought are the most obvious examples of this (Kudat, 2018, p. 197).

We have stated that the growth and progress policies implemented by developed states against developing or underdeveloped states have evolved into development strategies in the following period, and in the following processes, in particular, the goal of sustainable development by international institutions. Therefore, the sustainable development goals, which serve as a buffer for the problems created by capitalism's development, enrichment and growth policies and put on the market as a panacea, are also seriously questioned by many environments.

\section{G. Sustainable Development (SD)}

In 1987, the Brundtland Report, published systematically by the World Environment Commission under the title Our Common Future; 'Economic the efficient use of resources economically, the protection of the environment and natural capital, and the equal distribution of the benefits and costs of development between time and spatial units (Visser \& Brundtland, 2013). From this date onwards, the concept of SD started to enter our daily life quickly, first with its Rio Declaration and Agenda 21 report; it took its place in international politics and then all local and national policies in a short time. The concept of sustainability refers to the possibility of sustaining an opportunity or action; development is defined as increasing individual and social welfare in general. In order to continue its conceptual continuity, many fields such as sustainable energy, sustainable agriculture, sustainable tourism, sustainable environment and sustainable life have been associated with this subject, numerous studies have been conducted, symposiums and congresses have been organized and many publications related to this subject have been put forward in academic circles (Çokişler \& Çokişler, 2017).

The adverse effects of the current economic development targets on the environment, people, society and International level have been emphasized both in our study and in many other studies (Dulupçu, 2001). In this respect, the aim of the report is not only the improvement of economic indicators such as development, industrialization, growth and enrichment, but the equal and fair distribution of the benefits resulting from these improvements to all societies and all segments of the society, that is, increasing social welfare in all areas of the society (Visser \& Brundtland, 
2013).

There are three main areas where the objectives stated in the SD report are concentrated (Tiraş, 2012, pp. 60-61). These are determined as increasing economic development, protecting the environment and increasing social welfare (Figure 10). In order to increase and maintain the economic development, the world economy must grow 5-10 times more than the 1987 growth rates. The growth here refers to the growth in GNP rates. Environmental protection means preserving the ecological balance without destroying nature during development efforts. In addition, increasing social welfare includes many dimensions such as education, health, justice, social status, equality, political rights and freedoms in order to improve the quality of life beyond the basic needs of humanity.

Figure 10: Key Areas of Sustainable Development

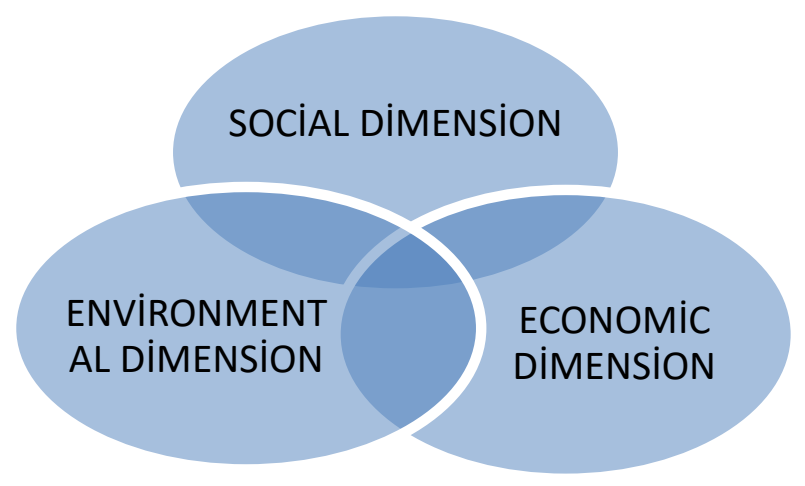

Source: (UN, 2015)

Although it has been enacted since its publication and in many state policies, it seems that the objectives of the SD have not been achieved. In their own reports, they only mention achievements: since 1990, more than 1 billion people have survived extreme poverty; since 1990, child mortality rates have decreased by more than half; since 1990, the number of drop-out children has decreased by more than half; since 2000, the HIV / AIDS transmission rate has decreased by about $40 \%$ (UN, 2015). In particular, equality of opportunity, social justice, income distribution, inequalities in the distribution of power and prosperity and freedom of much progress has not been achieved (Marcuse, 2016, p. 110). The story of a combination of capitalist understanding and the objectives of the CC has already been the subject of debate. The reason for this is that if there is profitability in a capitalist economy and profit maximization is to be increased, IP targets can be applied. Otherwise, high-cost environmental measures, social justice and 
the elimination of inequality are issues that do not profit in capitalist thinking and do not respond individually.

Because no business that is not profitable and cannot maximize the benefit of the individual in terms of profitability can find a place in capitalist thinking (Doğaner, 2002, p. 6; Marcuse, 2016, p. 107). On the other hand, the assumption that the needs are unlimited is the main argument of capitalist thought. The limitation of the individual in terms of consumption and production or the activities of observing the rights of another human being cannot find a place in capitalist thinking (Robinson, 2004, p. 371). However, it is the same resource that imposes the objectives of the CB on every platform and imposes on the world. From this point of view, it becomes a necessity that existing SD targets should be rethought.

On the other hand, the uncertainty of the definition of needs is one of the most important issues discussed in terms of SD objectives. From the first day of publication, it is impossible to construct and implement these goals on the uncertainty of what the concept of necessity is and how people will meet it under the changing world conditions (Harding, 2006, p. 234). The relationship between underdevelopment and sustainable development is another issue discussed. The claim that the underdeveloped countries should be included in the world economic system under free market conditions, and thus the achievement of IP targets, is not considered reasonable by many social scientists and economists. The most important reason of this is that these goals are seen as a trap that underdeveloped countries have developed by the developed states in order to ensure their dependence on them and to provide hegemony under the name of global government (Bozoğlu, 2008)

In addition, the emphasis is on the economic aspect of development and the neglect of its social aspect and the pursuit of policies that aim at economic development and push human development to the background. It is another critical issue that the developed countries contradict with the targets such as production, industrialization and technological investments determined in the framework of development and the policies which have an understanding that makes human beings superior to the environment while doing these are another critical issue (Robinson, 2004, p. 376)

\section{H. SDG Country Statistics}

In 1990, the World Bank adopted the poverty line of one dollar per day according to purchasing power in order to monitor the international poverty level, make comparisons among countries and use in the analysis. This rate was increased to 1.90 dollars in 2015 due to the criticism and changing real 
conditions from the determined day. Those with the income below 1.25 dollars were grouped into the extreme poverty group. Although this rate is suitable for measurement in emerging countries where subsistence standards are very low, such as Bangladesh, it is not a rate that measures poverty as the minimum cost of living in developed or developing countries is higher. Therefore, global poverty reports do not fully reflect the truth.

The implementation of SDG at the country level and achieving its goals necessitates very serious financial support for developing countries. For example, the financing required for Bangladesh's SDG strategy is USD 928 billion (Paul, 2019), which corresponds to approximately $20 \%$ of the country's GDP. Since the burden of the public sector in this strategy is very heavy, it also imposes a serious burden on the country budget. Lack of financial resources makes it impossible to achieve sustainable development goals. Four per cent of the population is below the extreme poverty line, and $31 \%$ is below the poverty line, which is 3.20 dollars per day. The malnutrition rate is $70.1 \%$ in both adults and children and has a large population close to the hunger limit (Sachs, 2020).

\section{Sustainable Development in terms of Islamic Economics}

It is an indisputable fact that we need universal development goals that are human-centered and embody the system of values, which are a common denominator for all, that make social benefit superior to individual benefit and apply justice to all spheres of social life. The following verses of the Qur'an bear ample testimony on the point (Quran, 6:3 and ff)

It is He Who created the heavens and the earth In true -proportions(Quran,6:3). Mischief has appeared on land and sea because of (the need) that hands of men have earned(Quran, 30:41). He created the heaven and the earth in true -proportions- (Quran,39:5) Verily, all things have We created in proportion and measure (Quran, 54:49). He Who created the seven heavens one above another; No want of proportion will thou see in the Creation of Allah) Most Gracious. So turn thy vision again. Seest thou any flaw? Again turn thy vision a second time (thy) vision will comeback to thee dull and discomfited, in a state worn out (Quran, 67:3-4).

It can be said that the objectives of the Islamic economic thought are generally theoretically acceptable. However, with some exceptions, it is generally in line with Islamic economic thought. However, the criticisms are mainly related to the dimension of the implementation of the objectives. For example, it is almost impossible to implement these targets, which are perceived as a general rule everywhere and always, for many reasons, 
especially in underdeveloped countries. Keep people alive and state that we need universal development goals dominated by the understanding of life, we think that the objectives of the SD should be revised and regulated in these respects.

\section{Human and Need Concept}

According to traditional economic theories and especially the paradigm that has been dominant since the 20th century, human beings have a individualistic structure. This paradigm argues that the choice of individual should be the basis for the person who has to make and choose. According to this basic assumption, human is associated with the definition of individual rationality or home economicus and aims to achieve resource maximization and resource limitation by prioritizing personal interests. Human needs are unlimited in this respect; resources are considered to be limited.

Although the choice and preference of the individual is the most important factor here, it is unclear to what extent he will make these choices and preferences. It is unanswered, such as what needs are, to what extent they are limited, and what behavior should be fulfilled when meeting the needs. According to Islamic economics, the definition of human being that exhibits rational behavior in any case, considering personal interest concerns, is not acceptable.

The economic, social programs and development plans that will be created by taking human-value approach as the center will raise the backward countries to the level of developed countries and make the world we live in more livable for everyone. In terms of Islamic economics, it is a fundamental philosophy that Allah, who is the owner of the universe, creates enough resources for all mankind and provides for each living thing separately. Therefore, defending the thesis that the resources are not enough and will run out is against the realities of existence of the universe. While most of the history of humanity is behind us, there is no data on the lack of resources. This thesis, which is put forward by calculating the population accounts and the existing resource distribution, is consistently far from being grounded. It is unacceptable to build a thought on assumptions and to implement them. Because, Muslims argue that the world's resources will be sufficient to meet human needs if they are used efficiently and fairly. And they do not admit that human needs are unlimited. Moreover, they believe that world resources should be used efficiently without wasting(Chapra, 1995, p. 6).

For the reasons mentioned above, it is necessary to eliminate the 
ambiguity of the definition of needs in the targets determined in terms of meeting the needs of current and future generations within the SD targets and to make a definition in order to protect the value judgments of human beings and to set appropriate targets accordingly. In this study, in general terms, human is an individual who is aware of the blessings that are given to him, who can make donations and donations by considering the situation of others, saves his economic and social needs without wasting and contributes to the production by means of the remaining opportunities (Figure 11).

Figure 11: Human Factor in Islamic Economic Thought

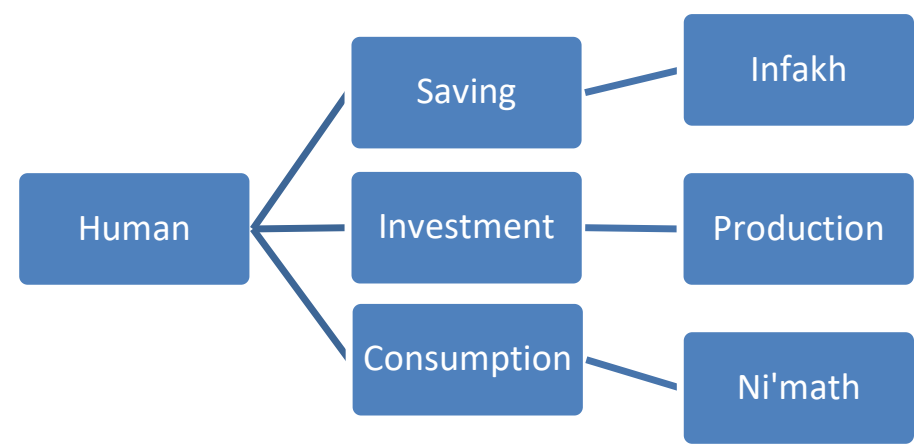

Source: Inspired by the author M.Umar Chapra's Book Islam and Economic Challange

\section{a. In terms of Priority of Development}

Both the Rio Declaration and Agenda 21 reports show that economic development is centered on the objectives of CB. The main reference of human development was envisaged as economic development and the plans for social development were ignored. In this respect, there is a need not only for an economic program that focuses on the economy, but also for applications that put people at the center and establish their development in every aspect. There is also a need for a serious revision of the definition of development as mentioned in the above chapters of the SD objectives. The application of these objectives which foresee economic growth as a development will not contribute to the solution of the problems. According to this perspective development; in addition to quantitative evaluation of the economy, it is an inclusive concept that requires qualitative aspects to be taken into consideration and even the developments in many different areas outside the economy should be taken into consideration (Doğaner, 2002, pp. 1-3).

Since Islamic economic thought is accepted as a social entity, human development actions should be considered as a whole and evaluated in 
social, human, economic, political and environmental aspects. However, economic development is only one title in this holistic structure.

\section{b. In Terms of Determination of Application Areas}

Existing SD targets are requested to be implemented in the same way everywhere from the day of announcement. This applies not only to the less developed countries but also to the developed countries. However, there is a difference between countries in terms of development area and needs. However, the objectives of the SD are regulated in the interstate documents mostly in line with the interests and objectives of the developed countries(Çokişler \& Çokişler, 2017). A participatory democracy cannot be mentioned when setting these goals. In other words, it was put forward by the hands of certain states without consultation with the peoples of the world. For African countries where there are starving people, the regulation on the emission of greenhouse gases makes no sense (Robinson, 2004). Because, in a region where people cannot meet their food needs, they cannot reach to clean water and unhealthy living conditions prevail, many IP targets are suspended. For this reason, it is necessary to determine the targets of IP according to each country or region and to implement the programs according to the needs of that region. From this point of view, we argue that in this study, it is necessary to determine specific IP targets according to each region and not according to general-valid conditions as Islamic Economic thought.

\section{c. In Terms of Establishing Social Justice}

Although the concept of Social Justice first appeared in the literature since the 1840s, it is seen that this concept was used much earlier. The history of the emergence of theoretical and practical applications related to this concept dates back to the 19th century and the objective is to eliminate the defective aspects of capitalism and to develop a fair market economy (Orman, 2016b).

Beyond meeting basic vital needs as Islamic economic thought, improving the quality of life of people regardless of language, religion, race, benefiting from halal nutrition, education, health, justice and environmental services, social justice, equality, political participation and representation are the social dimension of development.(Sneddon et al., 2006, p. 256). The concept of social justice, which is based on the combination of all these factors, is seriously neglected in today's world and occurs with many imbalances between societies. In order to eliminate this, all institutions and organizations participating in the society, especially the state, should carry 
out the works in order to create equal opportunities in the services and practices to be put forward, to ensure that everyone benefits from equal rights and services, to make the weak one strong and equal, and to complete the missing sides in terms of human values(Chapra, 1995, p. 252).

\section{In Terms of Establishing Social Justice}

Although the Concept of Social Justice first appeared in the literature since the $1840 \mathrm{~s}$, it is seen that this concept was used much earlier. The history of the emergence of theoretical and practical applications related to this concept dates back to the 19th Century, and the objective is to eliminate the defective aspects of capitalism and to develop a fair market economy (Orman, 2016a, pp. 3-4).

Increasing urbanization with the industrial revolution has led to the gradual decline of traditional institutions in the society that establishes social welfare and the emergence of new organizations - like trade unions - and even the responsibility of this issue has almost become a burden on the state (Koray, 2003, pp. 95-110). In the 1970s, with the effect of liberal policies, struggling with the problems in the social field began to be burdened with other social organizations in the society instead of the state (Gümüş, 2018, pp. 42-51). With the distribution of institutional social responsibility to all components of society (state-society), it may be possible to model the contribution of Islamic Economy to reduce social injustices and establish sustainable prosperity as follows;

Table. 2: The Contribution of Islamic Economy

\begin{tabular}{|c|c|c|c|}
\hline $\begin{array}{l}\text { Institutions in } \\
\text { Terms of Social } \\
\text { Responsibility }\end{array}$ & Corporate Types & $\begin{array}{l}\text { Basic } \\
\text { Responsibilities }\end{array}$ & $\begin{array}{l}\text { Social } \\
\text { Responsibility } \\
\text { Functions }\end{array}$ \\
\hline Religion & $\begin{array}{l}\text { Official and Non- } \\
\text { Official Religious } \\
\text { Institutions }\end{array}$ & $\begin{array}{l}\text { Spiritual } \\
\text { Consciousness, } \\
\text { Balanced Life, } \\
\text { Working } \\
\text { Consciousness, } \\
\text { Struggle Against } \\
\text { Difficulties and } \\
\text { Moral Motivation }\end{array}$ & $\begin{array}{l}\text { Providing } \\
\text { consultancy services } \\
\text { to the sociological } \\
\text { base on values } \\
\text { education, moral } \\
\text { teachings, social and } \\
\text { religious issues }\end{array}$ \\
\hline Public Institutions & $\begin{array}{l}\text { Central } \\
\text { Government and } \\
\text { Local Governments } \\
\text { Related Public } \\
\text { Institutions }\end{array}$ & $\begin{array}{l}\text { Effectively managing } \\
\text { the country's } \\
\text { resources and } \\
\text { distributing them to } \\
\text { the community } \\
\text { members fairly, } \\
\text { discovering and } \\
\text { developing people's } \\
\text { talents and skills, }\end{array}$ & $\begin{array}{l}\text { Preventing poverty, } \\
\text { meeting basic life } \\
\text { needs (education, } \\
\text { health, food, water, } \\
\text { transportation, etc.), } \\
\text { planning the future } \\
\text { of the society, } \\
\text { allocating funds, } \\
\text { supporting projects }\end{array}$ \\
\hline
\end{tabular}


The Role of Islamic Economy in Reduction of Social Injustice and Sustainable Development Goals

creating a conscious

society culture.

Foundations,

Civil Society Awqaf, Non-Profit

Organizations

Organizations,

Trade Unions,

Clubs, Associations

and Congregations
Social awareness, moral support and social aid activities

Sustainable support, education, the meeting material and moral needs and organizations in social issues, gaining an understanding of volunteering, social support services with projects preventing individualization

All activities aimed at increasing social welfare in the Goods and Services Sector,

Manufacturers, Businesses, Industrial Organizations and Service Sector
Providing Employment, Goods and Services working with social responsibility

awareness, employment mobilization focusing on human values

Preparing projects that will contribute to society in education, culture and social solidarity, reducing social problems by supporting nonrefundable grant supports, moneysaving funds and microfinance organizations, prioritizing support for investments with employment priority

It is possible to carry out the social responsibility consciousness that it has created based on all the structures and basic axioms that the Islamic economy embodies above, in cooperation with its rich institutional infrastructure (Yeniçeri, 2009, pp. 48-49). The effective execution of these duties belonging to social responsibility awareness will significantly contribute to reducing social injustices by establishing social protection. Most of the individual activities that exist in the Islamic tradition and in 
today's Muslim societies, but are carried out scattered without a center, should be turned into a strong organization and turned into a social policy, followed and controlled. For example, the UN Economic and Social Council (ECOSOC), which determines all aspects of sustainable development and policies within the scope of "Agenda 2030" by the UN, and the High Level Political Forum (HLPF), which is responsible for the supervision of this, is an organization that should also be in Islamic countries (UNDP, 2019). Organizations such as the Organization of Islamic Cooperation, the Organization of the Islamic Conference, D-8, the Arab League and the Asean community should meet each year and produce serious projects and carry out concrete studies instead of publishing oral and written declarations. This ore, which exists in the yeast and its potential of Islamic society, has not been activated yet.

Beyond meeting basic vital needs as Islamic economic thought, improving the quality of life of people regardless of language, religion, race, benefiting from halal nutrition, education, health, justice and environmental services, social justice, equality, political participation and representation are the social dimension of development (Sneddon et al., 2006, p. 256). The concept of social justice, which is based on the combination of all these factors, is seriously neglected in today's world and occurs with many imbalances between societies. In order to eliminate this, all institutions and organizations participating in the society, especially the state, should carry out the works in order to create equal opportunities in the services and practices to be put forward, to ensure that everyone benefits from equal rights and services, to make the weak one strong and equal, and to complete the missing sides in terms of human values (Chapra, 1995, p. 252).

\section{In Terms of Ignoring Historical Experience and Practices}

Although SD belongs to the nineteenth century as a concept, there are many practices in past societies and especially in Islamic thought that aim to ensure the prosperity of people and enable social development. However, the dominant paradigm is ignoring these and similar historical experiences and is seeking to rediscover the wheel according to its own design.

The foundation culture, zakat policies and microfinance practices in Islamic thought can be considered as alternative SD targets. Sustainable production and consumption opportunities were created by creating a foundation culture in Islamic societies, regular funding sources were provided for those in need, it served as a transfer from rich to poor to provide social welfare and carried out a strong development function by providing 
nutrition, education and health services (Gundogdu, 2018, p. 389).

The concept of SD is not a one-way concept, but has multiple components. Therefore, all segments of society should participate in this activity. Government, non-governmental organizations, associations and foundations have to contribute to the realization of these objectives. Longterm and costly social support activities such as SD and poverty alleviation cannot be left to the state alone. In this respect, our foundation culture is a historical indication that this is applicable.

Zakat practices are also very functional in this respect and have served many social benefits in the course of historical adventure. As an alternative to interest-rate microfinance institutions, interest-free microfinance institutions have also been established over the years and the financing methods used in Islamic banking have been used. After the 2000s, a microcredit instrument based on karz-i-hasen, which did not impose any burden on the entrepreneur other than debt, was also used and gained considerable success. Thus, the poor entrepreneur has the opportunity to have the capacity of life water, which can stand on its own feet, by keeping all the profits within its own structure(Yunus, 1987, p. 31). With this structure, ancient foundations and karz-1 hasen institutions met with the modern microfinance institution and a strong model emerged to reduce the problems of poverty and income distribution today (Kudat, 2018, p. 51). In this respect, microfinance applications are extremely important for SD and are highly functional to make the society productive(Chapra, 1995, p. 329).

\section{Conclusions and Recommendations}

The devastating effect of capitalist thought on developed countries by the developed countries and the fact that this trap is in effect in many countries is an indicator of the imbalance of the world. The gradual accumulation of wealth in the hands of a single class also leads to the impoverishment of a very large mass of people living in the world. According to the World Bank data, 3.5 billion people corresponding to half of the world's population earn less than 5 USD per day and live a poor life. Muslim countries account for half of this population. Therefore, it is understood that the countries most in need of global development goals are Muslim societies(Chapra, 1995, pp. 342-344).

Although the objectives of the SD have aroused excitement in many places from the time it was published, the difficulties of implementation and many reasons that have developed in the future have weakened the belief in the SD and failed to solve the problems. Uncertainty of the definition of need, 
setting goals on the axis of capitalist thinking, not wanting to apply the same practices everywhere, ignoring regional and country differences, having an economy-centered structure, ignoring other areas, claiming that it is environment-centered, and not including environmental policies, weakening and leading to failure (Masca, 2009, p. 197).

In terms of Islamic economics, some of the SD objectives seem to be acceptable. Considering the main points of action of the objectives of the Islamic economics, it is seen that there are serious problems. In addition, it is seen that Islamic economics as a complementary element has the potential to produce some solutions and allow new applications. Foundation culture, zakat practices and interest-free microfinance instruments in Islamic society should be considered in this respect (Chapra, 1995, p. 213).

In order for the Islamic world to implement SD programs, it should work to eliminate the backwardness and poverty, colonial exposure and conflicts within itself. Development against backwardness, full independence against colonialism and full Islamic unity against division should be established. Institutions such as Islamic Conference, Islamic Development Bank and D-8 should contribute to this process. While these problems persist, it is seen that the implementation of SD targets is impossible.

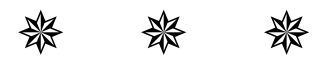

\section{BIBLIOGRAPHY}

Abdalla, M. (1999). Partnership (Musharakah): A New Option for Financing Small Enterprises? Arab Law Quarterly, 14(3), 257-267.

Abdullah, M. (2018). Waqf, Sustainable Development Goals (SDGs) and Maqasid al-Shariah. International Journal of Social Economics, 45(1), 158-172. https://doi.org/10.1108/IJSE-10-2016-0295

Ahmed, H., Mohieldin, M., Verbeek, J., \& Aboulmagd, F. (2015). On the Sustainable Development Goals and the Role of Islamic Finance. The World Bank. https://doi.org/10.1596/1813-9450-7266

Askari, H., Iqbal, Z., \& Mirakhor, A. (2008). New Issues in Islamic Finance and Economics: Progress and Challenges (1st Edition). Singapore: Wiley.

Asutay, M. (2007). A Political Economy Approach to Islamic Economics: Systemic Understanding for an Alternative Economic System (SSRN Scholarly Paper No. ID 1735619). Rochester, NY: Social Science Research Network. Retrieved from Social Science Research Network website: https://papers.ssrn.com/abstract=1735619 
Barry, B. (2017). Sosyal Adalet Neden Önemlidir (E. Kllıç, Trans.). Koc Üniversitesi Yayinlari.

Beaud, M. (2016). Kapitalizmin Tarihi: 1500-2010 (F. Başkaya, Trans.). İstanbul: Yordam Kitap.

Bilo, C., \& Machado, A. C. (2020). The Role of Zakat in the Provision of Social Protection: A Comparison Between Jordan and Sudan. International Journal of Sociology and Social Policy, 40(3/4), 236-248. https://doi.org/10.1108/IJSSP-11-2018-0218

Bozoğlu, B. (2008, February 11). Sürdürülebilir Kalkınma'nın küresel çöküşü. Retrieved 8 March 2020, from Sendika.Org website: https://sendika63.org/2008/02/surdurulebilir-kalkinmaninkuresel-cokusu-baran-bozoglu-18230/

Casas, B. de L. (1999). A Short Account of the Destruction of the Indies (1st Edition; A. Pagden, Ed.; N. Griffin, Trans.). London: Penguin Classics.

Chapra, M. U. (1995). Islam and the Economic Challenge. USA: The Islamic Foundation The International institute of Islamic Thought. Retrieved from

http://ierc.sbu.ac.ir/File/Article/Islam\%20and\%20the\%20Economi c\%20Challenge_93524.pdf

Çokişler, N., \& Çokişler, D. E. (2017). Critics of the Concept of the Sustainable Development. International Journal of Contemporary Tourism Research, 1(1), 1-7. https://doi.org/10.30625/ijctr.320412

Doğaner, F. G. (2002). Globalleşen Dünyada (Nasıl Bir) Sürdürülebilir Kalkınma. Birikim Yayıncılık, (158), 100.

Dulupçu, M. A. (2001). Sürdürülebilir Kalkınma Politikasına Yönelik Gelişmeler. Dış Ticaret Dergisi, 20, 46-70.

Emin, E. (2016). Dünya Yoksulluk ve Eşitsizlik Raporu (Araştırma No. 26; p. 24). İstanbul: İnsamer. Retrieved from İnsamer website: https://www.academia.edu/29989458/D\%C3\%BCnya_Yoksulluk_ve _E\%C5\%9Fitsizlik_Raporu

Er, İ. (2006). Kalkınma, Sosyal Adalet ve Sosyal Refah. In İslam'a Giriş. Ankara: DİB Yayınları.

Erdem, T. (2003). Yoksulluk Üzerine Sosyolojik Bir Araştırma: Ankara Kent Yoksulları (Yayınlanmamış Doktora Tezi). Hacettepe Üniversitesi Sosyal Bilimler Enstitüsü, Ankara.

Fârâbî, E. N. M. b. M. b. T. b. U. (1980). Es-Siyâsetü'l-Medeniyye. Ankara: Kültür Bakanlığı Yayınları. 
Fleischacker, S. (2013). Dağıtıcı Adaletin Kısa Tarihi (No. 42). İstanbul: Pinhan Yayıncılık. (TDV İslâm Araştırmaları Merkezi).

Gazzâlî, M. b. M. (1988). El-Mustasfâ. Kahire: Mektebet-ü Hancî.

Görmüş, Ş. (2015). İslam İktisadı İnsanlık için Bir İhtiyaç mı? Uluslararası İslam Ekonomisi ve Finansı Araştırmaları Dergisi, 1(2), 161-170.

Gümüş, İ. (2018). Tarihsel Perspektifte Refah Devleti: Doğuş, Yükseliş Ve Yeniden Yapılanma Süreci. Journal of Political Administrative and Local Studies, 1(1), 33-66.

Gundogdu, A. S. (2018). An Inquiry into Islamic Finance from the Perspective of Sustainable Development Goals. European Journal of Sustainable Development, 7(4), 381-381. https://doi.org/10.14207/ejsd.2018.v7n4p381

Harding, R. (2006). Ecologically sustainable development: Origins, implementation and challenges. Desalination, 187(1), 229-239. https://doi.org/10.1016/j.desal.2005.04.082

Hasan, Z. (2006). Sustainable Development from an Islamic Perspective: التنمية المستدامة من منظور إسلامي: Meaning, Implications and Policy Concerns Journal of King Abdulaziz University-Islamic Economics, 19(1), 3-18. https://doi.org/10.4197/islec.19-1.1

Hayek, F. A. V. (1978). New Studies in Philosophy, Politics, Economics and the History of Ideas. Chicago: University of Chicago Press.

Hudaefi, F. A. (2020). How does Islamic Fintech Promote the SDGs? Qualitative Evidence from Indonesia. Qualitative Research in Financial Markets, ahead-of-print(ahead-of-print). https://doi.org/10.1108/QRFM-05-2019-0058

IMF. (2016). Global Monitoring Report 2015-2016 Development Goals in an Era of Demographic Change (p. 283). Washington,: The World Bank. Retrieved from The World Bank website: http://pubdocs.worldbank.org/en/503001444058224597/GlobalMonitoring-Report-2015.pdf

Ismail, A. G., \& Shaikh, S. (2017). Role of Islamic Economics and Finance in Sustainable Development Goals. Malaysia: Islamic Economic Studies and Thoughts Centre (IESTC). https://doi.org/10.13140/RG.2.2.14806.09288 Piyasa Geliştirimi. In İslam İktisadı Kitaplı̆̆ı:2 (pp. 59-76). İstanbul: 
İgiad Yayınları.

Karakayalı, H. (2010). Kuramlarda Büyüme ve Kalkınma. Manisa: Emek Matbaası.

Kaypak, Ş. (2011). Küreselleșme Sürecinde Sürdürülebilir Bir Kalkınma İçin Sürdürülebilir Bir Çevre. Karamanoğlu Mehmetbey Üniversitesi Sosyal Ve Ekonomik Araştırmalar Dergisi, 2011(1), 19-33.

Kazgan, G. (2004). Íktisadi Düşünce veya Politik İktisadın Evrimi (11th ed.). İstanbul: Remzi Kitabevi.

Koray, M. (2003). Sosyal Refah Devleti: Kimi İçin Umut, Kimi İçin Kaygı Kaynă̆ı. İstanbul: SODEV-Tüses Yayıları.

Kuçuradi, İ. (2011). Insan Hakları: Kavramlar ve Sorunları. Ankara: Türkiye Felsefe Kurumu Yayınları.

Kudat, A. (2018). Sürdürülebilir kalkınma bağlamında vakfın özellikleri ve tecrübi hayatta yansimalarl: 1. International Waqf Instituon Symposium: Waqf and sustainable development: Proceedings Book. İstanbul Sabahattin Zaim Üniversitesi. Retrieved from http://openaccess.izu.edu.tr/xmlui/handle/20.500.12436/1213

Kurt, S. (2006). Hayek'in Özgürlük ve Adalet Teorisi. Uluslararası Yönetim Íktisat ve Issletme Dergisi, 2(3), 199-213.

Lucas, R. E. (1988). On The Mechanics of Economic Development. Journal of Monetary Economics, 22(1), 3-42. https://doi.org/10.1016/03043932(88)90168-7

Macit, M. (2005). Müslüman Ülkeler ve Kalkınma Sorunu. Osh Devlet Üniversitesi Illahiyat Fakültesi Dergisi, (7), 67-74.

Marcuse, P. (2016). Sustainability is not enough: Environment and Urbanization. (Sage CA: Thousand Oaks, CA). https://doi.org/10.1177/095624789801000201

Masca, M. (2009). Sürdürülebilir Kalkınma: Kalkınma ve Doğa Arasında Denge Arayışları, Uluslararası Davraz kongresi: Küresel diyalog ; 24-27 Eylül 2009 = International Davraz Congress: Social and economic issues shaping the world's future, new global dialogue ; 24-27 September 2009. Isparta: Süleyman Demirel Üniversitesi İktisadi ve İdari Bilimler Fakültesi.

Mevdûdî, E.-A. (2014). İslam Ekonomisinin Temel İlkeleri. İstanbul: Çıra Yayınları.

Miller, D. (1999). Principles of Social Justice. Harvard University Press. 
Nozick, R. (2001). Anarchy, State and Utopia. Malden, MA: Basic Book Inc.

OECD. (2012). Development Co-operation Report 2012. Paris: OECD Publishing.

Orman, S. (2016a). Gazali'nin İktisat Felsefesi (6th ed.). İstanbul: İnsan Yayınlarl. Retrieved from https://www.kitapyurdu.com/kitap/gazalinin-iktisatfelsefesi/62030.html

Orman, S. (2016b). İslam Entelektüel Geleneğinde İktisadi Boyutun Teşekkülü: Şeybânî, Serahsî Ve Kitâbu'l-Kesb (III). İslam Ekonomisi ve Finansı Dergisi (IEFD), 2(1), 19-54.

Osman, M. A. (1999). The Experience of the Sudanese Islamic Bank in Partnership (Musharakah) Financing as a Tool for Rural Development among Small Farmers in Sudan. Arab Law Quarterly, 14(3), 221-230.

Özsağir, A. (2008). Dünden Bugüne Büyümenin Dinamiği. Karamanoğlu Mehmetbey Üniversitesi Sosyal Ve Ekonomik Araştırmalar Dergisi, 2008(1), 332-347.

Paul, T. C. (2019, May 21). Bangladesh: Journey towards achieving Sustainable Development Goals (SDGs). The Financial Express. Retrieved from https://thefinancialexpress.com.bd/public/index.php/views/bangla desh-journey-towards-achieving-sustainable-development-goalssdgs-1558451988

Peterson, W. C. (1994). Gelir, İstihdam ve Ekonomik Büyüme (T. Güllap, Trans.). Erzurum: Atatürk Üniversitesi Yayınları.

Quran. (1998). The Qur'an: Text, Translation, and Commentary (Fourth U.S. Edition edition; A. Y. Ali, Trans.). Elmhurst, NY: Tahrike Tarsile Qur'an.

Rawls, J. (1999). A Theory of Justice (2nd Edition). Cambridge, Mass: Belknap Press: An Imprint of Harvard University Press.

Robinson, J. (2004). Squaring the circle? Some thoughts on the idea of sustainable development. Ecological Economics, 48(4), 369-384. https://doi.org/10.1016/j.ecolecon.2003.10.017

Romer, P. M. (1986). Increasing Returns and Long-Run Growth. The Journal of Political Economy, 94(5), 1002-1037.

Rousseau, J. J. (2017). Insanlar Arasındaki Eşitsizliğin Kaynağı (16th ed.). İstanbul: Say Yayınları.

|148| Sachs, J. at all. (2020). Sustainable Development Report 2020. Cambridge: 
The Role of Islamic Economy in Reduction of Social Injustice and Sustainable Development Goals

Cambridge University Press. Retrieved from Cambridge University Press website: https://sdgindex.org/reports/sustainabledevelopment-report-2020/

Sadr, K. (1999). The Role of Musharakah Financing in the Agricultural Bank of Iran. Arab Law Quarterly, 14(3), 245-256.

Savaș, V. (2000). İktisadın Tarihi (4th ed.). Ankara: Siyasal Kitabevi.

Schumpeter, J. A. (1936). [Review of Review of The General Theory of Employment, Interest and Money, by J. M. Keynes]. Journal of the American Statistical Association, 31(196), 791-795. JSTOR. https://doi.org/10.2307/2278703

Seibel, H. D. (2008). Islamic Microfinance in Indonesia: The Challenge of Institutional Diversity, Regulation, and Supervision. Sojourn: Journal of Social Issues in Southeast Asia, 23(1), 86-103. JSTOR. Retrieved from JSTOR.

Seyidoğlu, H. (1999). Uluslararası Íktisat-Teori, Politika ve Uygulama (13th ed.). İstanbul: Güzem Yayınları.

Sirgy, M. J. (2008). Ethics and Public Policy Implications of Research on Consumer Well-Being: Journal of Public Policy \& Marketing, 27(2), 207-212. https://doi.org/10.1509/jppm.27.2.207

Smith, A. (1982). Early draft of part of the wealth of nations. In M. R. L., R. D.D., \& S. Peter (Eds.), The Glasgow Edition of the Works and Correspondence of Adam Smith, Vol. 5: Lectures on Jurisprudence: Vol. Vol:5 (p. 654). London: Oxford University Press. Retrieved from https://www.oxfordscholarlyeditions.com/view/10.1093/actrade/9 780198281887.book.1/actrade-9780198281887-book-1

Smithies, A. (1951). Schumpeter and Keynes. The Review of Economics and Statistics, 33(2), 163-169. JSTOR. https://doi.org/10.2307/1925880

Sneddon, C., Howarth, R. B., \& Norgaard, R. B. (2006). Sustainable development in a post-Brundtland world. Ecological Economics, 57(2), 253-268. https://doi.org/10.1016/j.ecolecon.2005.04.013

TheCityUK. (2019). Global trends in Islamic finance and the UK market 2019

I TheCityUK. Retrieved 29 September 2020, from https://www.thecityuk.com/research/global-trends-in-islamicfinance-and-the-uk-market-2019/

Tiraş, H. H. (2012). Sürdürülebilir Kalkınma Ve Çevre: Teorik Bir İnceleme. Kahramanmaraş Sütçü İmam Üniversitesi İktisadi ve İdari Bilimler Fakültesi Dergisi, 2(2), 57-73. 
UN. (2015). Sürdürülebilir Kalkınma Amaçları. Retrieved 9 March 2020, from UNDP Türkiye website: https://www.tr.undp.org/content/turkey/tr/home/sustainabledevelopment-goals.html

UNDP. (2019). 2019 Küresel Çok boyutlu Yoksulluk Endeksi. Retrieved from https://www.undp.org/content/dam/turkey/UNDP-TR-MPI-2019TR.pdf

United, N. (2016). Human Development Report 2016: Human Development for Everyone. New York: UN. https://doi.org/10.18356/b6186701-en

United Nations. (1987). Report of the World Commission on Environment and Development: Our Common Future.

United Nations (Ed.). (2006). Social Justice in an Open World: The Role of the United Nations. New York: United Nations.

Visser, W., \& Brundtland, G. H. (2013). Our Common Future ('The Brundtland Report'): World Commission on Environment and Development. The $\begin{array}{llll}\text { Top } 50 \quad \text { Sustainability } & \text { Books, }\end{array}$ https://doi.org/10.9774/gleaf.978-1-907643-44-6_12

Wallerstein, I. (1983). Tarihsel Kapitalizm (N. Alpay, Trans.). İstanbul: Metis Yayınlarl.

Wid.World. (2018). World Inequality Report 2018. WID.WORLD. Retrieved from WID.WORLD website: https://wir2018.wid.world/files/download/wir2018-summaryturkish.pdf

Yavilioğlu, C. (2002). Kalkınmanın anlambilimsel tarihi ve kavramsal kökenleri,. C. Ü. İktisadi ve İdari Bilimler Dergisi, 3(1), 59-77.

Yeniçeri, C. (2009). İslam'ın Emeğe Bakışı ve Emek Hayatını Düzenlemesi.

Yunus, M. (1987). The Poor as the Engine of Development. The Washington Quarterly, 10(4), 139-145. https://doi.org/10.1080/01636608709477624

Zâim, S. (1995). İslam, Insan,Ekonomi (II). İstanbul: Yeni Asya Yayınları.

Zaman, A. (2008). Islamic Economics: A Survey of the Literature (Working Paper No. 22). UK: University of Birmingham. https://doi.org/10.2139/ssrn.1282786.

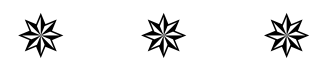




\title{
SOSYAL ADALETSİZLİKLERİN AZALTILMASI VE SÜRDÜRÜLEBİLİR KALKINMA HEDEFLERİ AÇISINDAN İSLAM EKONOMISIINİN ROLÜ
}

\begin{abstract}
Geniş Öz
Gelecek nesillerin ihtiyaçlarını karşılayabilme olanağından ödün vermeksizin günümüz neslinin ihtiyaçlarını karşılayabilecek bir kalkınma modeli olarak ilan edilen "sürdürülebilir kalkınma", 20. yüzyıl sonlarına doğru dünya gündeminde yerini almış ve 1990'lı yıllarda imzalanan uluslararası antlaşmalarla küresel bir uygulama planı haline gelmiștir. Küresel anlamda gelir dağılımındaki eşitsizlikleri azaltma, yoksullukla mücadele ve sürdürülebilir bir refah anlayışını dünya geneline hakim kılma, çevresel ve ekolojik sorunlarla mücadele etme gibi bir çok insani hedefi amaçlayan bu politika ilk dönemlerden itibaren ilgi uyandırmış ve bir çok devlet tarafından da politika aracı olarak kullanılmıştır.

Küresel düzeyde varlığını sürdüren gelir adaletsizliği ve kat kat artan yoksulluk oranları günümüz dünyasının karşılaştığı en ciddi sorunlardan birisi haline gelmiş ve sürdürülebilir kalkınma politikalarının işlevi tartışılmaya başlanmıştır. 1980'lerle başlayan hızlı değişim süreciyle birlikte gelir dağılımı sorunu sıradan bir ekonomi sorunu olmaktan çıkmış politik ve sosyal bir sorun olarak algılanmaya başlanmıștır. Dünya ölçeğinde 1950'li yıllardan itibaren uygulanan ve günümüzde de değişik boyutlarıyla sürdürülmeye çalışılan sosyo-ekonomik politikalar var olan olumsuzlukları ve yoksulluğu daha da belirgin hale getirmiştir iddiasıyla birçok eleştiriye maruz kalmıştır.

Mevcut küresel sistemde finansal açıdan daha da zenginleşen dünya diğer taraftan birçok sosyal problemi de beraberinde getirerek toplumsal refahın azaldığı dengesiz bir yapıya bürünmüştür. Diğer bir tartışma konusu da sosyo-ekonomik bir yaklaşım ile çevresel ilişkileri ele alan kalkınma stratejilerinin etkin bir şekilde kullanıldığında bugünün ihtiyaçlarına cevap verme açısından verimli olabileceği ancak gelecek nesillerin ihtiyaçlarını
\end{abstract}

a Arş. Gör., Süleyman Demirel Üniversitesi, muhammetyurtseven@sdu.edu.tr

b Dr. Öğr. Üyesi, KTO Karatay Üniversitesi, kamola.bayram@karatay.edu.tr 
tüketmek açısından da ciddi zararlara yol açabileceği hususu olmuştur. Ayrıca ekonomik büyümenin sınırları konusunda net bir yaklaşım olmadığı için boyutlarının ne olacağı sorusu da belirsiz kalmıştır. Bu yüzden sürdürülebilir kalkınma stratejilerinin tüm yönleriyle ele alınması ve mevcut sorunların giderilerek daha makul ve uygulanabilir bir sistemsel yapıya kavuşturulması elzemdir. Sürdürülebilir kalkınma stratejileri ile gelir dağılımındaki adaletsizlikleri İslam ekonomisi perspektiften ele alabilmek için bu konudaki politik kararlığın İslam ülkeleri tarafından ortaya konulması gerekmektedir. Bugüne kadar ortaya konulmuş politikaların yeniden gözden geçirilmesi, var olan gelişmelerin eksik yönlerinin belirlenerek tamamlayıcı önerilerin sunulması ve ortaya çıkan güncel tehdit ve fırsatların iyi belirlenmesi gerekmekte olup bu çalışma da bu amaca katkı sunmak adına hazırlanmıştır.

Çalışmamızda nicel araştırma yöntemlerinden tümevarım metodu kullanılmış olup öncelikle tarihi dönemlendirmelerden hareketle iktisadi düşünce içerisinde büyüme, ilerleme ve kalkınma kavramları incelenmiştir. Tarihsel olarak incelenen bu süreçten sonra mevcut kalkınma strtejileri değerlendirilmiş, olumlu ve olumsuz yönleri ifade edilmiştir. Daha sonra İslam ekonomisinin büyüme ve kalkınma anlayışı ortaya konmaya çalışılmış ve sürdürülebilir kalkınma hedefleriyle karşılaştırması yapılmıştır. Ayrıca, İslam ekonomisinin geleceği sahiplenen bir anlayıșa sahip olmasından hareketle, (i)herkesin ve her kesimin ihtiyaçlarını karşılayacak daha yaşanabilir bir hayat ortaya konulacak politikaları, (ii) gelir dağılımındaki adaletsizlikleri giderecek ve tam anlamıyla sürdürülebilir kalkınma anlayışının oluşmasına katkı sağlayacak stratejileri, (iii) hangi politika araçları ile bu kapsamı gerçekleştirebileceği ele alınmıştır. Bu çalışma tüm boyutlarıyla gelir adaletsizliği ve sürdürülebilir kalınma stratejilerini ele alarak İslam ekonomisinin sosyal vizyonunu ortaya koymayı hedeflemektedir.

İslam ekonomisinin sürdürülebilir kalkınma hedeflerini ontolojik olarak genel anlamda kabul ettiği söylenebilir. İnsani olanakların iyileştirilmesi adına dünyada ortaya konulan her çabanın aynı zaman da İslam ekonomisinin genel ilkeleriyle de uyumlu olduğu rahatlıkla söylenebilir. Bu konuda islam ekonomi anlayıșının bir itirazı yoktur. İslam ekonomi düşüncesi adına yapılan itiraz bu poltitkaların uygulanma felsefesiyle ilgilidir. Egemen ülkelerin geri kalmış ülkeler üzerinde daha da egemen olmasına olanak sağlayacak bu pratiklerin, geri kalmışlık, yoksulluk ve bölünmüşlük durumlarından beslenerek tahakküm aracına dönüştürülmesi kabul edilemez bir durumdur. Büyüme, ilerleme, kalkınma; bunun karşısında geri kalmış, az gelişmiş veya gelişmekte olan ülkeler gibi peşinen bir tasnifin yapılması, isimsel açıdan makul ancak içeriği rahatlıkla oynanabilecek politikalarla egemen devletlerin mazlum coğrafyalara tahakkümü, insanlığın ve İslamiliğin kabul etmeyeceği durumlardır. 
itibaren büyüme, ilerleme ve kalkınma kavramlarının analizini yapılarak bu konuya açıklık kazandırmaya çalışılacak ve günümüz iktisadi politikalarının bu kavramlara bakış açısını mukayese edilerek dönüşümün boyutlarını ortaya konulacaktır. Her toplumun veya devletin kendi kadri çabasınca bu kavramlara ilişkin poltikalar ürettiği ve bu uygulamalarında neredeyse evrensel olduğundan hareketle egemen devletlerin elinde adeta başkalaşım geçirerek birer politik silaha dönüştürüldügünün örnekleri de zikredilecektir.

İslam ekonomi anlayışında sürdürülebilir kalkınmaya yönelik politik adımların yanı sıra sosyal kurumlarında devreye sokularak bu alana ciddi katkılar sunacağına inamaktayız. Tarihi tecrübe içerisinde kendi toplumu genelinde ve temas ettiği diğer toplumlar özelinde düşünülürse inşa, imar ve sosyal açıdan toplumsal bir yaşanmışlık örneği önümüzde durmaktadır. İslam toplumlarında vakıf kültürü oluşturularak sürdürülebilir üretim ve tüketim olanakları oluşturulmuş, ihtiyaç sahipleri için düzenli finansman kaynakları sağlanmış, toplumsal refahın sağlanması için zenginden fakire bir transfer işlevi görmüş, beslenme, eğitim ve sağlık hizmetleri vererek güçlü bir kalkınma fonksiyonu yürütmüștür. Var olandan hareketle var olması gerekeni izah etme yöntemiyle İslam ekonomisinin bu konuda söyleyeceği çözüm önerilerine de değinilecektir. Vakıf, zekât, infak, sadaka, mikrofinans, imece, teâvün gibi sosyal uygulamaların sürdürülebilir kalkınmaya ne dendli bir ivme kazandıracağı da ele alınacaktır. İslam ekonomi düşüncesi içerisinde sosyal bir kurum olarak var olan vakıf kültürü, zekât politikaları ve mikrofinans uygulamalarının alternatif veya iyileştirici olması açısından SK politikalarına katkısı ve sosyal adaleti tesis etme potansiyeli değerlendirilecektir.

Anahtar Kelimeler: İslami Ekonomi, Sürdürülebilir Kalkınma, İslam, Adalet, Sürdürülebilir Kalkınma Hedefleri.

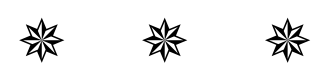

